\title{
Genetic Inactivation of Free Fatty Acid Receptor 3 Impedes Behavioral Deficits and Pathological Hallmarks in the APP Swe Alzheimer's Disease Mouse Model
}

\section{Marta Zamarbide}

CIMA: Centro de Investigacion Medica Aplicada

\section{Eva Martinez-Pinilla}

ISPA: Instituto de Investigacion Sanitaria del Principado de Asturias

Francisco J Gil-Bea

Centre for Applied Medical Research: Centro de Investigacion Medica Aplicada

Masashi Yanagisawa

University of Tsukuba: Tsukuba Daigaku

\section{Rafael Franco}

University of Barcelona Faculty of Biology: Universitat de Barcelona Facultat de Biologia

Alberto Pérez-Mediavilla ( $\square$ lamediav@unav.es)

Universidad de Navarra Facultad de Ciencias https://orcid.org/0000-0003-1926-0972

\section{Research Article}

Keywords: Alzheimer's disease, neuroprotection, therapy, synaptic plasticity, learning and memory, Amyloid

Posted Date: December 6th, 2021

DOI: https://doi.org/10.21203/rs.3.rs-1124827/v1

License: (c) (i) This work is licensed under a Creative Commons Attribution 4.0 International License. Read Full License 


\section{Abstract}

The free fatty acid FFA3 receptor (FFA3R) belongs to the superfamily of G-protein-coupled receptors (GPCRs). In the intestine and adipose tissue, it is involved in the regulation of energy metabolism but its function in the brain is unknown. We aimed, first, to investigate the expression of the receptor in the hippocampus of Alzheimer disease (AD) patients at different stages of the disease and, second, to assess whether genetic inactivation of the Ffar3 gene could affect the phenotypic features of the APP ${ }_{\text {swe }}$ mouse model.

The expression of transcripts for FFA receptors in post mortem human hippocampal samples and in the hippocampus of wild-type and transgenic mice was analyzed by RT-qPCR. We generated a double transgenic mouse, $\mathrm{FFA3R}^{-/-} / \mathrm{APP}_{\text {swe, }}$, to perform cognition studies and to assess, by immunoblotting, $A \beta$ and tau pathologies and the differential expression of synaptic plasticity-related proteins.

For the first time, the occurrence of the FFA3R in the human hippocampus and its overexpression, even in the first stages of $A D$, was demonstrated. Remarkably, $\mathrm{FFA3R}^{-1} / \mathrm{APP}_{\text {swe }}$ mice do not have the characteristic memory impairment of 12-month-old $\mathrm{APP}_{\text {swe }}$ mice. Also, this newly generated transgenic line does not develop the most important Alzheimer's disease (AD)-related features, such as amyloid beta $(A B)$ brain accumulations and tau hyperphosphorylation. These findings are accompanied by increased levels of the insulin-degrading enzyme (IDE) and lower activity of the tau kinases GSK3 $\beta$ and Cdk5. We conclude that the brain FFA3R is involved in cognitive processes and its inactivation prevents AD-like cognitive decline and pathological hallmarks.

\section{Introduction}

Alzheimer's disease (AD) is a neurodegenerative disorder among the elderly, characterized by progressive deterioration of cognition, with a complex etiology involving multiple processes [1]. Neuropathological features include senile plaques (SP), composed of aggregated amyloid $\beta$ peptides $(A \beta)$ derived from aberrant processing of the amyloid precursor protein (APP), neurofibrillary tangles (NFT), composed of hyperphosphorylated tau protein, and synaptic and neuronal loss [2]. In light of many recent studies, defects in lipid metabolism and consequent alterations in the membrane concentration of phospholipids may impact the development of pathophysiological features of AD [3-8]. In fact, the formation of SP and NFT correlates with decreased phospholipid biosynthesis and increased lipid degradation or peroxidation $[9,10]$ that contribute to synaptic impairment and neuronal loss [11]. In addition, cumulative evidence indicates that inflammation occurs in vulnerable regions of the AD brain, contributing significantly to the pathogenesis [12-14]. Moreover, recent research regarding the major genetic risk factor has been done about the impact of APOE genotype on microflora speciation. Interestingly, metabolomic analysis detected significant differences in microbe-associated amino acids and short-chain fatty acids (SCFA) between APOE genotypes indicating its association with specific gut microbiome profiles. These results suggest that further investigation related to the gut microbiome and fatty acids should be done to 
establish new targets able to mitigate the deleterious impact of the APOE4 allele on the cognitive decline associated with AD [15].

Free fatty acids (FFA) are part of phospholipids of neural cells, that are important for the proper development and physiology of neurons $[16,17]$. Indeed, the brain lipid content is about $50 \%$ of its dry weight confirming an essential role of lipids in the structure and functionality of the central nervous system (CNS) $[18,19]$. SCFA refer to carboxylic acids with aliphatic chains of less than 6 carbons, e.g. acetic, propionic, butyric or valeric acids, which may be synthesized in vivo. Long-chain fatty acids (LCFA) refer to carboxylic acids that are 13 to 21 carbons long, such as arachidonic (AA) and docosahexaenoic acids (DHA) often derived from food intake they can also be synthesized by de novo or via salvage pathways. Interestingly, lipid homeostasis alteration in neurodegenerative diseases leads to altered lysosomal function and autophagy, which in turn results in impaired processing of APP [20-23].

FFA regulatory effects are mediated by the receptors that belong to the superfamily of $G$ protein-coupled receptors (GPCRs). GPCRs constitute a large family of seven transmembrane domain membrane proteins that are activated by a huge variety of molecules. They play a key role in the mammalian homeostasis. GPCR activation may engage a variety of signaling molecules and activate (or deactivate) a diversity of signaling pathways $[24,25]$. Five FFA receptors (FFARs) have been identified: FFA1R (or GPR40) and FFA4R (or GPR120), which are selectively stimulated by LCFA, and FFA2R (or GPR43), FFA3R (or GPR41) and GPR42, which are selectively stimulated by SCFA. Moreover, there is an unconfirmed FFAR candidate, GPR84, which would be activated by medium-chain fatty acids [26-30]. Whereas it is not known much about the events mediated by GPR42, all other FFARs coupled to $G_{q}$ with the exception of the FFA3R which couples to $G_{i} / G_{0}$ [31]. FFA3R also regulates the activation of the mitogen-activated protein kinase (MAPK) pathway [32].

These receptors have been studied in depth in peripheral tissues, especially in adipose tissues and in the pancreas ([32-35] for review). FFARs are involved, among others, in adipocyte differentiation [36], insulin release by the pancreas [37] and growth hormone release by the pituitary gland [38]. Their expression and function have been less investigated in the central nervous system (CNS), although the participation of FFARs in some neuropathies has been suggested $[6,39,40]$.

In what concerns the FFA3R, the gene expression was analyzed by the GTEx Project in multiple reference human tissues by high-throughput RNAseq screening. FFA3R expression pattern presents higher levels in adipose tissue, breast, colon, spleen and digestive tract while neural expression was lower. In more detail, within the CNS, the highest levels were found in the spinal cord followed by substantia nigra, hypothalamus, caudate and hippocampus [6, 41].

Most of the studies regarding this receptor have been performed in the peripheral nervous system, demonstrating its expression on postganglionic sympathetic and sensory neurons in both the autonomic and somatic nervous system [42]. Moreover, it has been established that the FFA3R mediates the effects of SCFAs in sympathetic nervous system activity thus contributing to the control of body energy 
expenditure and metabolic homeostasis [43]. As SCFAs are the main metabolites produced by the microbiota they have a key role in the gut-brain crosstalk [44]. In line with this, recent studies focus on the study of this receptor in the gut-brain axis, whose recognized mechanisms are the modification of autonomic/sensorimotor connections, immune activation and regulation of the neuroendocrine pathway [45]. There is growing evidence of the role of the microbiota in the regulation of physiology and behavior in metabolic, inflammatory, and neurodegenerative disorders [46]. In fact, amelioration of motor deficits and reduction of dopaminergic neuronal loss in a mouse model of Parkinson's disease (PD) may be achieved via regulating FFA3R expression in the enteric nervous system by the bacteria that inhabit the gut [47].

Since lipids are important for brain structure and function, and ketone bodies, which may activate the FFA3R are an important energy source for neurons, we hypothesized that the receptor could be a target for AD. Accordingly we focused the potential expression of the FFA3R in the hippocampus and on assessing what would be the consequence of a lack of the receptor in an transgenic mice model. Hence, the aim of this work was to investigate the expression of the receptor in the hippocampus of AD patients and, second, to assess whether genetic inactivation of the Ffar3 gene could affect the phenotypic features of one $A D$ mice model. For this purpose, a new transgenic line was developed by crossing the

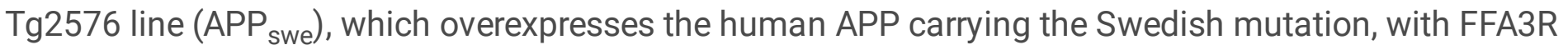
knockout (KO) $\left(\mathrm{FFA3R}^{-/-}\right)$mice.

\section{Materials And Methods}

\section{Human brain samples}

Human brain samples (specifically, the hippocampal region) came from the Navarra Health Service/Osasunbidea's Research Biobank came from patients who met the criteria for the diagnosis of AD-like pathology with Braak stages from III to $\mathrm{VI}$ and symptoms of dementia, and from non-demented individuals with no AD pathology (Table 1). All procedures were carried out in accordance with the Ethics Committee of the University of Navarra and, for all subjects, written informed consent for whole body autopsy, and for the removal of all organs for diagnostic and research purposes, was obtained from their next of kin. Brain samples were stored at $-80^{\circ} \mathrm{C}$ until processing. 
Table 1

Demographic and neuropathological characteristics of the subjects included in this study

\begin{tabular}{|lllll|}
\hline Braak stage & Cases $(\mathbf{n})$ & M/F & Age*, year & PMD*, $\mathbf{h}$ \\
\hline ND & 6 & $4 / 2$ & $35.5(19-54)$ & $3.2(2.15-6)$ \\
\hline Braak III-IV & 4 & $2 / 2$ & $83.5(76-89)$ & $2.5(2-3.37)$ \\
Braak V & 4 & $0 / 4$ & $87(77-92)$ & 2.3 \\
Braak VI & 6 & $1 / 5$ & $84.2(79-89)$ & $2.3(1,25-3.3)$ \\
* median and (range). & & & \\
ND = non demented; $F=$ female; $M$ = male; PMD = postmortem delay; $\mathrm{h}$ = hours \\
\hline
\end{tabular}

\section{Animals and behavior test}

In this study, we used groups of 12-month-old ( $n=44 ; n=24$ females and $n=20$ males) of four genotypes: $\mathrm{APP}_{\text {swe, }}, \mathrm{FFA3R}^{-/-} / \mathrm{APP}_{\text {swe, }} \mathrm{FFA3R}^{-/-}$mice and WT littermates. APP swe mice express the human 695-aa isoform of the APP containing the Swedish double mutation $\left(\right.$ APP $_{\text {swe }}$ ) [(APP695)Lys670 $\rightarrow$ Asn, Met671 $\rightarrow$ Leu] driven by a hamster prion promoter, were used as a mouse model of $A D$ [48]. $\mathrm{FFA3R}^{-/-}$and $\mathrm{FFA3R}^{-/-} / \mathrm{APP}_{\text {swe }}$ mice were generated in our laboratories by breeding $\mathrm{FFA3R}^{-/-}$mice with $\mathrm{APP}_{\text {swe }}$ mice [49]. The animals were maintained in positive pressure-ventilated racks at $25 \pm 1^{\circ} \mathrm{C}$ with a $12 \mathrm{~h} \mathrm{light/dark}$ cycle, fed ad libitum with a standard rodent pellet diet (Global Diet 2014; Harlan), and allowed free access to filtered and UV-irradiated water. All animal care and experimental procedures were in accordance with European and Spanish regulations (86/609/CEE; RD1201/2005) and were approved by the Ethical Committee of the University of Navarra (no. 018/05). Behavioral studies were carried out during light time (from 9 am to $2 \mathrm{pm}$ ). Details about the genotyping of the different mice strains can be found in Supplement 1.

\section{Morris water maze test (MWM)}

Groups of 12-month-old $\mathrm{APP}_{\text {swe }}, \mathrm{FFA3R}^{-/-} / \mathrm{APP}_{\text {swe }}$ and $\mathrm{FFA3R}^{-/-}$mice and WT littermates, underwent spatial reference learning and memory in the Morris water maze (MWM) test, a hippocampus-dependent learning task as described previously [50]. The day before the behavioral test, animals were housed in the ad hoc room for acclimatization and maintained in the room until test completion. The water maze was a circular tank (diameter $1.2 \mathrm{~m}$ ) filled with water at $20^{\circ} \mathrm{C}$ and made opaque by the addition of non-toxic white paint. Mice underwent visible-platform training for three consecutive days ( 6 trials/day), and were allowed to swim to a raised platform (diameter $10 \mathrm{~cm}$ ) located above the water in the same position over the trials. No distal visible cues were present during this phase. Hidden-platform training was conducted over 8 consecutive days ( 4 trials/day). Mice had $60 \mathrm{~s}$ to find a hidden platform submerged $1 \mathrm{~cm}$ beneath the surface of the water and invisible to the mice while swimming. Several large visual cues were placed in the room to guide the mice to the hidden platform. In both visible- and hidden-platform versions, mice 
were placed pseudo-randomly in selected locations, facing towards the wall of the pool to eliminate the potentially confounding contribution of extramaze spatial cues. Mice that failed to reach the platform were guided onto it. All of the animals were allowed to rest on the platform for $20 \mathrm{~s}$ and then removed from the platform and returned to their home cage. At the beginning of the 4th, 7th, and 9th day of the task a probe trial, in which the platform was removed from the pool, was conducted and the mice were permitted to search the platform for $60 \mathrm{~s}$. All trials were monitored by a camera above the center of the pool connected to a SMART-LD program (Panlab S.L., Barcelona, Spain) for subsequent analysis of escape latencies, swimming speed, path length and percent time of spent in each quadrant of the pool during the probe trials. Mice that were unable to reach the visible-platform, exhibiting abnormal swimming patterns or persistent floating were excluded from data analyses. All experimental procedures were performed blind to groups.

\section{Fear conditioning-based memory induction protocol}

To induce the immediately early genes, all the animals were placed under a cognitive stimulus based on a fear conditioning test as described previously [51]. Details can be found in Supplement 1. Two hours after the fear conditioning test, the animals were killed and the brains removed for biochemical studies.

\section{Brain tissue processing for immunohistochemistry}

Under xylazine/ketamine anesthesia, animals were perfused transcardially with saline and $4 \%$ paraformaldehyde (PFA) in phosphate buffer (PB). $1 \mathrm{~h}$ post-fixation step with $4 \%$ PFA was done before the overnight cryoprotection step in $30 \%$ sucrose solution in PB at $4^{\circ} \mathrm{C}$. Microtome sections $(30 \mu \mathrm{m}$-thick) were cut coronally and stored in cryopreservation solution at $-20^{\circ} \mathrm{C}$ until processed. For the immunohistochemistry, nine free floating tissue sections comprising the hippocampal formation of three animals per group were processed. Immunohistochemistry was performed in nine free floating tissue sections comprising the hippocampal formation of three animals per group. Details about immunohistochemistry protocol can be found in Supplement 1.

\section{Protein extracts}

Mice were killed by cervical dislocation and hippocampi were quickly dissected from the brains. Total tissue homogenates were obtained by homogenizing the hippocampus in a cold lysis buffer with protease inhibitors $(0.2 \mathrm{M} \mathrm{NaCl}, 0.1 \mathrm{M}$ HEPES, 10\% glycerol, $200 \mathrm{mM} \mathrm{NaF}, 2 \mathrm{mM}$ Na4P2O7, $5 \mathrm{mM}$ EDTA, 1 mM EGTA, 2 mM DTT, 0.5 mM PMSF, $1 \mathrm{mM} \mathrm{Na3V04,} 1 \mathrm{mM}$ benzamidine, $10 \mu \mathrm{g} \cdot \mathrm{mL}-1$ leupeptin, 400 $\mathrm{U} \cdot \mathrm{mL}-1$ aprotinin). After that, the homogenates were centrifuged at $14.000 \times \mathrm{g}$ for $20 \mathrm{~min}$ at $4^{\circ} \mathrm{C}$ and the supernatant was aliquoted and stored at $-80^{\circ} \mathrm{C}$. Total protein concentrations were determined using the Bio-Rad Bradford protein assay (Bio-Rad, Hercules, CA, USA).

To obtain the membrane-enriched protein fraction (P2 membrane proteins), a previously described method [52] was used. The hippocampi were homogenized in ice-cold Tris-EDTA buffer (10 mM Tris-HCl and $5 \mathrm{mM}$ EDTA, pH 7.4), containing $320 \mathrm{mM}$ sucrose and the protease and phosphatase inhibitors previously described. The tissue homogenate was centrifuged at $700 \times \mathrm{g}$ for $10 \mathrm{~min}$. The collected 
supernatant was centrifuged again at $37.000 \times \mathrm{g}$ for 40 min at $4^{\circ} \mathrm{C}$. Finally, the pellet (P2) was resuspended in $10 \mathrm{mM}$ Tris-HCl buffer $(\mathrm{pH} 7.4)$, containing the enzyme inhibitor mixture described above. In both cases, protein concentration was determined (Bradford assay, Bio-Rad, CA, USA) and aliquots were stored at $-80^{\circ} \mathrm{C}$ until use. For western blot analysis, aliquots of the $\mathrm{P} 2$ membrane fraction were solubilized in denaturing conditions by adding 0.1 volumes of $20 \%$ SDS and $50 \% \beta$-mercaptoethanol. The samples were incubated for $5 \mathrm{~min}$ at $100^{\circ} \mathrm{C}$ and diluted $1: 20$ in $50 \mathrm{mM}$ Tris- $\mathrm{HCl}(\mathrm{pH} \mathrm{9)/0.1 \%} \mathrm{Triton} \mathrm{X-100.}$ After a centrifugation step at $37.000 \times \mathrm{g}$ for $10 \mathrm{~min}$ at $4^{\circ} \mathrm{C}$, the supernatant was stored at $-80^{\circ} \mathrm{C}$.

For APP-derived carboxy-terminal fragments (CTFs) determination, the cortex was homogenized in a buffer containing SDS $2 \%$, Tris- $\mathrm{HCl}(10 \mathrm{mM}, \mathrm{pH} 7.4)$, protease inhibitors (Complete Protease Inhibitor Cocktail, Roche) and phosphatase inhibitors (0.1 mM Na3V04, $1 \mathrm{mM} \mathrm{NaF}$ ). The homogenates were sonicated for $2 \mathrm{~min}$ and centrifuged at $100.000 \times \mathrm{g}$ for $1 \mathrm{~h}$. Aliquots of the supernatant were frozen at $-80^{\circ} \mathrm{C}$ and protein concentration was determined by the Bradford method using the Bio-Rad protein assay (Bio-Rad, Hercules, CA, USA).

\section{Determination of $A \beta$ levels}

For the analysis of soluble $A \beta_{42}$ burden, the same protein extraction that was used for APP-derived CTFs determination was followed. Soluble $A \beta_{42}$ levels were determined by using a sensitive sandwich ELISA kit from Biosource (Camarillo, CA, USA) following the manufacturer's instructions.

\section{Immunoblotting}

Protein samples were mixed with 6X Laemmli sample buffer resolved onto SDS-polyacrylamide gels [53] and transferred to nitrocellulose membrane. For the analysis of APP-derived CTFs, protein extracts were separated in a Criterion ${ }^{\mathrm{TM}}$ precast Bis-Tris 4-12\% gradient precast gel (Bio-Rad, Hercules, CA, USA) and transferred to nitrocellulose membranes. Details and a list with primary and secondary antibodies used can be found in Supplement 1.

\section{RNA extraction and quantitative reverse transcription PCR (RT-qPCR)}

Total RNA was extracted from the brain hippocampus by Chomczynski and Sachi's method [54] with the TRI reagent (Sigma-Aldrich, MO, USA). Details of RNA extraction and RT-qPCR as well as a table with the primer sequences for quantitative PCR can be found in Supplement and Supplement Table 1.

\section{Data analysis and statistical procedures}

The data were analyzed with SPSS for Windows version 15.0 (SPSS, Chicago, IL, USA) and, unless otherwise indicated, the data are expressed as the means \pm standard error of the mean (S.E.M.). The normal distribution of data was checked by the Shapiro-Wilks test. In the MWM, latencies to find the platform were examined by two-way repeated-measures ANOVA test (genotypextrial) to compare the cognitive status in WT mice, $\mathrm{APP}_{\text {swe }}, \mathrm{FFA3R}^{-/-}$and FFA3R ${ }^{-/ /} / \mathrm{APP}_{\text {swe. }}$. Likewise, the spatial memory and the biochemical data were examined also by a two-way ANOVA test (treatment $\times$ trial) followed by post hoc 
Tukey's analysis. When the interaction between factors was significant, single effects were analyzed by one-way ANOVA followed by post hoc Tukey's test. When no significant interaction between factors was found, the main effects were analyzed. Student's t-test was used when two groups were compared.

\section{Results}

Expression of transcripts for FFA receptors in post mortem human hippocampal samples

The study of FFAR expression was performed in human hippocampi of post mortem non-demented (ND) individuals and individuals with AD. By RT-qPCR we found both, that transcripts for FFA1R, FFA3R and FFA2R are expressed in the human hippocampus and that their expression is altered in AD. Considering Braak and Braak stages [55] here was a decrease of FFA1R levels in the early stages of AD, compared with ND controls $(p<0.001)$, and an increase with the course of the pathology. The increase, however, never reached the amount found in ND individuals (Fig. 1A). FFA2R transcript levels were significantly decreased $(50-60 \%)$ in AD patients in relation to ND controls ( $p<0.001)$, without significant differences through the stages of the pathology (Fig. 1B). Remarkably, FFA3R transcripts increased by circa 5 -fold at the early stages of the disease $(p<0.001)$. The level was still increased in stage $\mathrm{V}$ although it went down to the control at later stages $(p<0.01)$ (Fig. 1C).

Expression of transcripts for FFA receptors in the hippocampus of WT and transgenic mice

Hippocampal expression of FFAR in mice was assessed by RT-qPCR. We found a significant increase in FFA1R transcript expression levels in FFA3R $\mathrm{R}^{-/-}$mice ( $p<0.001$ vs WT mice) and also in FFA3R ${ }^{-/-} / \mathrm{APP}_{\text {swe }}$ compared with $\mathrm{APP}_{\text {swe }}$ mice $(p<0.05)$. By contrast, a decrease of FFA1R mRNA level was found in samples from $\mathrm{APP}_{\text {swe }}$ mice ( $p<0.01$ vs WT mice) (Fig. 2A). Meanwhile, the FFA2R transcript level was significantly downregulated in $\operatorname{APP}_{\text {swe }}(p<0.01)$, FFA3R $^{-/-}(p<0.05)$ and FFA3R ${ }^{-/-} / \mathrm{APP}_{\text {swe }}(p<0.01)$ compared with WT mice (Fig. 2B). Finally, FFA3R transcripts were overexpressed in the hippocampi of $\mathrm{APP}_{\text {swe }}$ mice $(p<0.001$ vs WT mice) (Fig. 2C).

Genetic inactivation of FFA3R reverses the cognitive impairment of APP $_{\text {swe }}$ mice

To assess spatial reference learning and memory function, groups of 12 -month-old FFA3R ${ }^{-/-}, \mathrm{FFA3R}^{-/}$ $-/ \mathrm{APP}_{\text {swe }}$ and $\mathrm{APP}_{\text {swe }}$ mice and the corresponding age-matched control littermates (10-12 mice per group) were tested in the MWM. No statistically significant differences in escape latency among groups were found during the visible platform training (Fig. $3 \mathrm{~A}$ ). In the spatial reference training (invisible platform), we found escape latencies signi』cantly shorter in WT, FFA3R ${ }^{-/-}, \mathrm{FFA3R}^{-/-} / \mathrm{APP}_{\text {swe }}$ than in $\operatorname{APP}_{\text {swe }}$ mice $(p<0.01)$ (Fig. 3B).

The measurement of memory retention was performed in the pool without the platform. On day 4, no

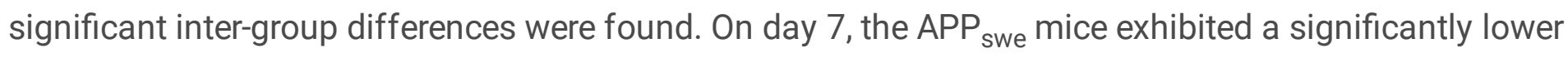
proportion of time spent in the target quadrant compared with WT, $\mathrm{FFA3R}^{-/-}$or $\mathrm{FFA3R}^{-/-} / \mathrm{APP}_{\text {swe }}$ mice 
$\left(\mathrm{APP}_{\text {swe }}\right.$ vs WT, $\left.p<0.01 ; \mathrm{APP}_{\text {swe }} v s \mathrm{FFA3R}^{-/-}, p<0.001 ; \mathrm{APP}_{\text {swe }} v s \mathrm{FFA3R}^{-/-} / \mathrm{APP}_{\text {swe, }}, p<0.05\right)$. On day 9 , the $\mathrm{APP}_{\text {swe }}$ mice exhibited again a significantly lower proportion of time spent in the target quadrant compared with WT, FFA3R ${ }^{-/-}$and FFA3R $\mathrm{R}^{-/-} / \mathrm{APP}_{\text {swe }}$ mice ( $\left.p<0.05\right)$ (Fig. 3C). The swim speed did not differ significantly between groups, and the distance data exhibited the same pattern as the escape latency (data not shown). These results demonstrate that FFA3R ${ }^{-/-} / \mathrm{APP}_{\text {swe }}$ mice show a better cognition status as assessed by the MWM test.

$\mathrm{A} \beta$ pathology is reversed in the brain of $\mathrm{FFA3R}^{-/-} / \mathrm{APP}_{\text {swe }}$ mice

$A \beta$ burden is one of the most relevant $A D$-like features in the $A P P_{\text {swe }}$ line. The effect of $F f a 3 R$ knockdown on $A \beta$ production and fibrillar $A \beta$ depositions were determined. ELISA measurement in cortical homogenates shows barely detectable levels of $A \beta_{42}$ in 12-month-old FFA3R $\mathrm{R}^{-/-} / A P P_{\text {swe }}$ mice, as opposed to what happens in age-matched $\mathrm{APP}_{\text {swe }}$ mice, which have high levels of this polypeptide (Fig. 4A). No $A \beta_{42}$ was detected in non-transgenic littermates and $\mathrm{FFA3R}^{-/-}$mice (data not shown).

We analyzed the APP-derived CTFs processing in these animals by western blot. As it is shown in figure 4B, there were no significant differences in the levels of the CTFs (C83 and C99) between FFA3R ${ }^{-/-}$vs WT

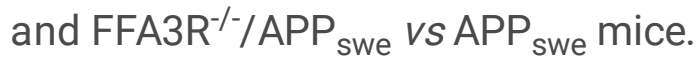

Interestingly, immunohistochemical analysis of hippocampal and frontal cortex sections using 6E10 antibody demonstrates that $F F A 3 R^{-/-} / A P P_{\text {swe }}$ mice are completely free of $A \beta$ deposits, which were

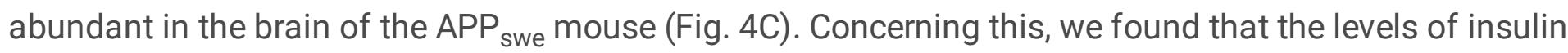
degrading enzyme (IDE), which reduces the accumulation of APP-derived toxic peptides, were increased in the hippocampus of $\mathrm{FFA3R}^{-/-}$and FFA3R $\mathrm{F}^{-/-} / \mathrm{APP}_{\text {swe }}$ mice (FFA3R $\mathrm{F}^{-/-} v s \mathrm{WT}, p<0.01 ; \mathrm{FFA3R}^{-/-} / \mathrm{APP}_{\text {swe }}$ $v s \mathrm{WT}, p<0.001 ; \mathrm{FFA3R}^{-/-} / \mathrm{APP}_{\text {swe }}$ vs $\left.\mathrm{APP}_{\text {swe, }}, p<0.01\right)$. Therefore, the $\mathrm{A} \beta$ reduction, both soluble and fibrillar, could be a consequence of higher clearance mediated by $A \beta$ degrading enzymes. Whereas IDE was increased, no significant inter-group differences in the expression of neprilysin transcripts were detected (Fig. 4D, E).

Hippocampus of $\mathrm{FFA3R}^{-/-} / \mathrm{APP}_{\text {swe }}$ mice shows a decrease in tau pathology

Hyperphosphorylation of tau protein is another of the main hallmarks of $A D$ so we explore the possible neuropathological correlation with memory improvement in $\mathrm{FFA3R}^{-/ /} / \mathrm{APP}_{\text {swe }}$ mice. 12-month-old $\mathrm{FFA3R}^{-/-/ A P P_{\text {swe }}}$ mice displayed significantly reduced levels of phosphorylated tau, at the epitopes recognized by the AT8 antibody $\left(\mathrm{Ser}^{202} / \mathrm{Thr}^{205}\right)$, compared with the $\mathrm{APP}_{\text {swe }}$ transgenic mice. No significant change in phosphorylated tau levels was found in the $\mathrm{FFA3R}^{-/-}$mice compared with nontransgenic controls (Fig. 5A). 
We then looked for changes in kinase activity accounting for the reduction of tau phosphorylation. The results showed an increase in the tau kinase GSK3 $\beta$ active form, phosphorylated at $\mathrm{Tyr}^{216}$, in $\mathrm{APP}_{\text {swe }}$ mice compared with WT mice ( $p<0.001$ ) (Fig. 5B). FFA3R $\mathrm{R}^{-1 /} / \mathrm{APP}_{\text {swe }}$ mice showed significantly lower levels of active GSK3 $\beta$ as compared with APP swe mice $(p<0.001)$ and similar to WT mice. Also, the inactive form of GSK3 $\beta$, phosphorylated at Ser ${ }^{9}$, was increased in $\mathrm{FFA3R}^{-/ /} / \mathrm{APP}_{\text {swe }}$ vs $\mathrm{APP}_{\text {swe }}(p<0.001)$ (Fig. $\left.5 \mathrm{C}\right)$.

It has been demonstrated that Cdk5 kinase, which phosphorylates tau, is activated by p35 proteins and hyperactivated by its proteolytically-derived product $p 25$. The analysis of the $p 25 / p 35$ ratio in $A_{P P} P_{\text {swe }}$ mice showed a significant increase $\left(p<0.01\right.$ APP $_{\text {swe }}(1,63 \pm 0,07)$ FFAR3 $^{-/-} / \mathrm{APP}_{\text {swe }}(0,75 \pm 0,10)$ when compared with data obtained in samples from WT animals. This altered ratio, which likely contributes to the tau pathology observed in the $\mathrm{APP}_{\text {swe }}$ mouse, was significantly decreased $(p<0.01)$ in the double

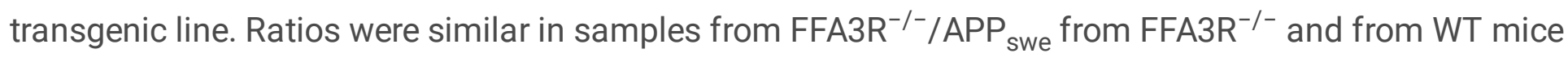
(Fig. 5D).

$\mathrm{FFA3R}^{-/-} / \mathrm{APP}_{\text {swe }}$ mice show an increase in mature BDNF and the expression of synaptic plasticityrelated proteins

Memory consolidation is a process to stabilize short-term memory, generating long-term memory by the expression of several immediate early genes (IEGs) [56]. To assess the biochemical substrate for memory recovery, we have analyzed the expression of several IEG products. In order to induce the expression of genes related to memory consolidation, animals were given fear conditioning training and sacrificed $2 \mathrm{~h}$ later (Fig. 6A). Then, the levels of the synaptic activity-dependent proteins, c-Fos, Arc and the phosphorylation of the CREB transcription factor were determined by western blot using hippocampal samples from these animals. Compared with data in samples from WT mice, the hippocampus of APP swe $_{\text {swe }}$ animals showed a reduction of $52 \pm 7 \%(p<0.001), 68 \pm 3 \%(p<0.05)$ and $66 \pm 5 \%(p<0.01)$ in c-Fos, Arc and pCREB levels, respectively. However, we did not find differences in the amount of these proteins when comparing samples from WT, FFA3R $\mathrm{R}^{-/-}$and FFA3R $\mathrm{R}^{-/-} / \mathrm{APP}_{\text {swe }}$ mice (Fig. 6B, C, D).

The brain-derived neurotrophic factor (BDNF) is involved in neural synaptic development. Compared with data in samples from WT mice, the hippocampus of $A_{P P}$ swe animals showed a decrease in $\mathrm{mBDNF} /$ proBDNF ratio $(p<0.05)$ due to a significant increase in proBDNF levels $(p<0.01)$. Although not significant, the $\mathrm{mBDNF} / \mathrm{proBDNF}$ ratio in samples from $\mathrm{FFA3R}^{-/-} / \mathrm{APP}_{\text {swe }}$ was in between from those found in WT and APP swe mice (Fig. 7).

To better understand the basis of good performance in the MWM test displayed by 12-month-old FFA3R ${ }^{-/}$ ${ }^{-} / \mathrm{APP}_{\text {swe }}$ mice, we also wanted to address synaptic plasticity in the cortex as it is also involved in AD pathology and the consolidation of new memory circuits. First, the ionotropic AMPA receptors were found increased in both $\mathrm{FFA3R}^{-/-}$and $\mathrm{FFA3R}^{-/-} / \mathrm{APP}_{\text {swe }}$ mice. In fact, the results showed a statistically significant increase in the phosphorylation of the AMPA subunit GluR1 in FFA3R ${ }^{-/-}$and FFA3R ${ }^{-/-} /$APP $_{\text {swe }}$ 


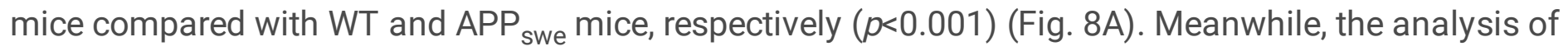
GluR2 and GluR3 AMPA subunits exhibited an increase in their expression levels in $\mathrm{FFA3R}^{-/-} / \mathrm{APP}_{\text {swe }} v s$ $\mathrm{APP}_{\text {swe }}$ mice and WT mice ( $\left.p<0.05\right)$ (Fig. 8B).

Cytoskeletal protein PSD95, a member of the post-synaptic density, is decreased in APP $_{\text {swe }}$ mice $(p<0.05$ vs WT mice) and its levels are recovered in the FFA3R ${ }^{-/-} / \mathrm{APP}_{\text {swe }}$ mice $\left(p<0.001\right.$ vs APP $_{\text {swe }}$ mice $)$ and in $\mathrm{FFA3R}^{-/-}$compared with WT mice $(p<0.001)$ (Fig. 8C). MAP-2 shows similar cortical levels in the WT, $\mathrm{FFA3R}^{-/-}$and $\mathrm{FFA3R}^{-/-} / \mathrm{APP}_{\text {swe }}$ mice. Conversely, $\mathrm{APP}_{\text {swe }}$ mice have decreased levels of MAP-2 compared with WT mice $(p<0.05)$ (Fig. 8D).

Finally, the levels of the phosphorylated form of CaMK II are preserved in FFA3R ${ }^{-/-}$and $\mathrm{FFA3R}^{-/-} / \mathrm{APP}_{\text {swe }}$ mice whereas they are decreased in the $\mathrm{APP}_{\text {swe }}$ mice ( $p<0.01$ vs WT mice) (Fig. 8E). Comparing the transgenic animals the expression was higher in $\mathrm{FFA3R}^{-/-} / \mathrm{APP}_{\text {swe }}$ than in $\mathrm{APP}_{\text {swe }}$ mice.

\section{Discussion}

Over the past decades, researchers have made remarkable progress in understanding the molecular events that lead to the characteristic progressive decline in cognition and memory in $A D[57,58]$. Despite these efforts, current therapies for $A D$ can only temporarily improve symptoms of memory loss without delaying the course of the disease, i.e. the death of neurons and the decline in higher cognitive functions [59]. Growing evidence demonstrates that defects in lipid metabolism and, consequently, alterations in vesicular dynamics and synaptic plasticity are related to the pathogenesis of $A D[6,60]$. Recently, it has been demonstrated that the plasma lipidome is dysregulated in AD. Specifically, AD patients show several alterations in levels of different lipid classes: sphingomyelins, cholesterol esters, phosphatidylcholines, phosphatidylethanolamines, phosphatidylinositols and triglycerides [61], but no differential results were obtained in relation to SCFA lipids. SCFAs as propionate or valerate, whose deficiency has been associated with $A D$, can influence plasma membrane organization and activity through the FFA3R [62, 63]. In fact, FFA3R is strongly expressed in the gut, where it has been studied extensively in intestinal motility and inflammation $[64,65]$. However, its expression and the role it may play in the CNS has not yet been adequately addressed. Although there is some evidence of their presence in the nervous system [6], the lack of studies in relation to these receptors is probably due to the difficulty of their characterization at the protein level due to the absence of specific antibodies.

In this study we demonstrated, for the first time, that FFARs are expressed in the human hippocampus of both control and AD patients. In addition, data on mRNA transcription levels in post mortem hippocampal tissue from $A D$ patients showed FFA3R overexpression in the early stages of the disease whereas FFA1R and FFA2R expression appeared down-regulated. We then reasoned that a transgenic mouse obtained by crossing an $A D$ mouse model with a FFA3R KO mice would provide insights into the potential of FFARs as therapeutic targets in the disease. We chose the $\mathrm{APP}_{\text {swe }}$ transgenic mouse, which is considered an early AD model [48], because it has a hippocampal pattern of FFA3R expression that mimics that found in 
patients at the early stages of the disease. As the most notable behavioral characteristic in AD models is memory impairment, we noted using the MWM test that the lack of FFA3R per se does not interfere with spatial memory. However, the main result of the study is that the FFA3R genetic defect $\left(\mathrm{FFA3R}^{-/-} / \mathrm{APP}_{\text {swe }}\right.$ mice ), which is overexpressed in the hippocampus of patients, completely reverses the characteristic cognitive deficits of 12-month-old APP swe $_{\text {mice }}[48,56,66,67]$. Differential expression in patients versus controls and this specific finding in double transgenic mice leads to the conclusion that blocking FFA3R function prevents memory loss in the context of AD.

Memory consolidation involves the expression of IEGs, which play a critical role in the transformation of neural events for the acquisition into long-term memories, mainly through cortico-hippocampal circuits $[68,69]$. IEG products such as PCREB, Arc and c-Fos are also reduced in the cerebral cortex and the hippocampus of another AD mice model, the APP/PS1 transgenic mice [70, 71]. A $\beta$ pathology also impacts on reducing the expression of functional Arc [72]. In this regard, our work shows that the lack of FFA3R restores the aberrant expression of IEGs in mice that overexpress the APP $_{\text {swe }}$ making them similar to the levels found in WT mice (graphical abstract). There is little information on the consequences of the activation of FFARs expressed in the CNS. It should be noted that, at the mechanistic level, the activation of FFA3R may induce the phosphorylation of CREB. The mechanism may be independent of alpha subunit of the canonical heteromeric $G$ protein of the receptor, $G_{i}$, because engagement of this protein would lead to a reduction in the levels of CAMP. We favor the hypothesis of involvement of beta-gamma subunits in linking receptor activation to CREB phosphorylation and IEG expression. A previous study shows that activation of FFAR1 induces the phosphorylation of CREB and of extracellular-regulated kinase (ERK) 1/2 in primary hippocampal neurons and in a human neuroblastoma cell line [73]. CREB signaling is known to regulate the expression of genes that promote synaptic and neuronal plasticity, including the gene for brain-derived neurotrophic factor (BDNF).

Synaptic activity plays a fundamental role in the consolidation of new memory circuits, and different enzymes, receptors and cytoskeletal proteins, whose levels are decreased in patients with $A D$, are involved [74]. APP $_{\text {swe }}$ mice show a reduction in the cytoskeletal proteins of dendritic spines such as PSD 95 and MAP-2, probably related to the accumulation of $A \beta$ [75]. Due to their role in memory consolidation and long-term improvement, these characteristics are also present in $A D$ patients [76]. Interestingly, we have found a similar expression of MAP-2 in FFA3R KO mice compared to WT mice, and higher levels of PSD 95 in FFA3R ${ }^{-/-}$and FFA3R ${ }^{-/-} / \mathrm{APP}_{\text {swe }}$ compared to WT mice. These findings might explain the restoration of cognitive status observed in $\mathrm{FFA3R}^{-/-} / \mathrm{APP}_{\text {swe }}$ mice. Moreover, we study the processing of BDNF, a neurotrophic factor that plays a key role in neuronal survival and, among others, in synaptic function and cognition [77]. ProBDNF is subsequently cleaved to form a mature protein, mBDNF [78, 79], which has been associated with AD [80]. O'Bryant et al., (2009), have documented a decrease in BDNF mRNA levels in post mortem brain samples of patients diagnosed with $A D$ and mild cognitive impairment [81]. It has also been suggested that serum BDNF levels are altered in $A D[82,83]$. Consistent with the 
main conclusion of this article, the decrease in the $\mathrm{mBDNF} /$ proBDNF ratio in $\mathrm{APP}_{\text {swe }}$ mice (compared to WT) was restored in the $\mathrm{FFA3R}^{-/-} / \mathrm{APP}_{\text {swe }}$ ones.

The significant decrease in SA $B$ content and the absence of SP in the hippocampus and cortex of the $\mathrm{FFA3R}^{-/-} / \mathrm{APP}_{\text {swe }}$ mice are consistent with the correlation of $\mathrm{SA} \beta$ levels, and the synaptic alterations and cognitive dysfunction exhibited by the transgenic $A D$ mice $[84,85]$. The absence of SP in the FFA3R ${ }^{-/}$

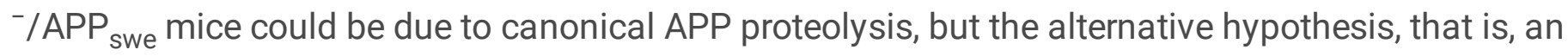
increase in A $\beta$ clearance seems more logical [86-88]. In fact, we did not observe any deficits in APP processing since the levels of $\mathrm{C} 83$ and $\mathrm{C} 99$ were identical to those of $A P P_{\text {swe }}$ mice. Interestingly, $\mathrm{FFA3R}^{-/}$

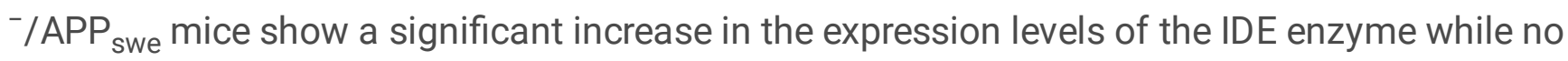
differences were found in the analysis of the expression levels of NEP. These data support the hypothesis that IDE promotes an increase in $A \beta$ clearance that reduces the accumulation of this harmful peptide in the brain. Cognitive impairment in transgenic AD models is also accompanied by accumulations of phosphorylated tau, which are composed of aberrant forms of phosphorylated tau [89-91]; indeed, higher activities of GSK3 $\beta$ and Cdk5 kinases result in accumulation of hyperphosphorylated tau in 12-month-old $\mathrm{APP}_{\text {swe }}$ mice [92-94]. The increase in the inactive $\mathrm{pGSK} 3 \beta-\mathrm{Ser}^{9}$ form in the FFA3R $\mathrm{R}^{-/-} / \mathrm{APP}_{\text {swe }}$ mice, along with a parallel decrease in the active pGSK3 $\beta$-Tyr ${ }^{216}$ form, may explain the significant decrease in aberrant tau phosphorylation.

In conclusion the data obtained in the present study indicate that FFA3R is expressed in the healthy human hippocampus and that a genetic deletion of the receptor results in the dissipation of the molecular and behavioral abnormalities shown by the $\mathrm{APP}_{\text {swe }}$ animal model. We hypothesize that the lack of FFA3R probably produces a different profile of FFAR expression which stimulates the clearance of soluble $A \beta$ content, by the activation of different signaling pathways, promoting the removal of senile plaques in the hippocampus and cortex by the increased expression of IDE. Consequently, FFA3R emerges as a therapeutic target to combat AD. Very relevant is the information on the chemical structures that differentially affect FFA3R-mediated signaling. Inverse agonists, antagonists, and negative allosteric modulators are now available [95-101] and could easily be tested for safety and efficacy in animal models of disease. Last but not least, future work should address the role of FFA3R in brain development, neurogenesis, and neurophysiological functions.

\section{Declarations}

\section{Statements and Declarations}

\section{Ethical approval}

All animal care and experimental procedures were in accordance with European and Spanish regulations (86/609/CEE; RD1201/2005) and were approved by the Ethical Committee of the University of Navarra (no. 018/05). 


\section{Funding}

This work was supported by the Foundation for Applied Medical Research (FIMA) intra-mural funds.

\section{Data availability}

The data that support the findings of this study are available from the corresponding author upon reasonable request.

\section{Competing interest}

The authors have no relevant financial or non-financial interests to disclose

\section{Author contributions}

All authors contributed to the study conception and design. Material preparation, data collection and analysis were performed by Marta Zamarbide, Eva Martínez-Pinilla, Francisco J Gil-Bea, Rafael Franco and Alberto Pérez-Mediavilla. Masashi Yanagisawa developed the FFAR3KO mouse line. The first draft of the manuscript was written by Marta Zamarbide, Rafael Franco and Alberto Pérez-Mediavilla.All authors commented on previous versions of the manuscript. All authors read and approved the final manuscript.

\section{Acknowledgments}

The authors are grateful to the Animal Research Facility at CIMA and acknowledge the technical help provided by Dr. June Sanchez and by Susana Ursúa.

\section{References}

1. Maccioni RB, Muñoz JP, Barbeito L (2001) The molecular bases of Alzheimer's disease and other neurodegenerative disorders. Archives of Medical Research 32:367-381 https://doi.org/10.1016/s01884409(01)00316-2

2. Di Domenico F, Sultana R, Barone E, et al (2011) Quantitative proteomics analysis of phosphorylated proteins in the hippocampus of Alzheimer's disease subjects. Journal of Proteomics 74:1091-1103. https://doi.org/10.1016/j.jprot.2011.03.033

3. Nagarathinam A, Höflinger P, Bühler A, et al (2013) Membrane-anchored A $\beta$ accelerates amyloid formation and exacerbates amyloid-associated toxicity in mice. The Journal of neuroscience: the official journal of the Society for Neuroscience 33:19284-19294. https://doi.org/10.1523/JNEUROSCI.254213.2013

4. Vitiello G, Di Marino S, D'Ursi AM, D'Errico G (2013) Omega-3 fatty acids regulate the interaction of the Alzheimer's a $\beta(25-35)$ peptide with lipid membranes. Langmuir: the ACS journal of surfaces and colloids 29:14239-14245. https://doi.org/10.1021/la403416b 
5. González-Domínguez R, García-Barrera T, Gómez-Ariza JL (2014) Combination of metabolomic and phospholipid-profiling approaches for the study of Alzheimer's disease. Journal of Proteomics 104:37-47. https://doi.org/10.1016/j.jprot.2014.01.014

6. Falomir-Lockhart LJ, Cavazzutti GF, Giménez E, Toscani AM (2019) Fatty Acid Signaling Mechanisms in Neural Cells: Fatty Acid Receptors. Frontiers in cellular neuroscience 13:162. https://doi.org/10.3389/fncel.2019.00162

7. Bascoul-Colombo C, Guschina IA, Maskrey BH, et al (2016) Dietary DHA supplementation causes selective changes in phospholipids from different brain regions in both wild type mice and the Tg2576 mouse model of Alzheimer's disease. Biochimica et biophysica acta 1861:524-537. https://doi.org/10.1016/j.bbalip.2016.03.005

8. Fonteh AN, Chiang AJ, Arakaki X, et al (2020) Accumulation of Cerebrospinal Fluid Glycerophospholipids and Sphingolipids in Cognitively Healthy Participants With Alzheimer's Biomarkers Precedes Lipolysis in the Dementia Stage. Frontiers in neuroscience 14:611393. https://doi.org/10.3389/fnins.2020.611393

9. Shimohama S, Fujimoto S, Tresser N, et al (1993) Aberrant Phosphoinositide Metabolism in Alzheimer's Disease. Annals of the New York Academy of Sciences 695:46-49. https://doi.org/10.1111/j.1749-6632.1993.tb23025.x

10. Canale C, Seghezza S, Vilasi S, et al (2013) Different effects of Alzheimer's peptide A $\beta(1-40)$ oligomers and fibrils on supported lipid membranes. Biophysical chemistry 182:23-29. https://doi.org/10.1016/j.bpc.2013.07.010

11. Svennerholm L, Gottfries CG (1994) Membrane lipids, selectively diminished in Alzheimer brains, suggest synapse loss as a primary event in early-onset form (type I) and demyelination in late-onset form (type II). Journal of neurochemistry 62:1039-1047. https://doi.org/10.1046/j.14714159.1994.62031039.x

12. Akiyama H, Barger S, Barnum S, et al (2000) Inflammation and Alzheimer's disease. Neurobiology of Aging 21:383-421. https://doi.org/10.1016/s0197-4580(00)00124-x.

13. Baron R, Babcock AA, Nemirovsky A, et al (2014) Accelerated microglial pathology is associated with $A \beta$ plaques in mouse models of Alzheimer's disease. Aging Cell 13:584-595. https://doi.org/10.1111/acel.12210

14. Nichols MR, St-Pierre MK, Wendeln AC, et al (2019) Inflammatory mechanisms in neurodegeneration. Journal of Neurochemistry 149:562-581. https://doi.org/10.1111/jnc.14674

15. Tran TTT, Corsini S, Kellingray L, et al (2019) APOE genotype influences the gut microbiome structure and function in humans and mice: relevance for Alzheimer's disease pathophysiology. FASEB 
journal: official publication of the Federation of American Societies for Experimental Biology 33:82218231. https://doi.org/10.1096/fj.201900071R

16. Uauy R, Mena P (2001) Lipids and neurodevelopment. In: Nutrition Reviews. International Life Sciences Institute, pp S34-S48. https://doi.org/10.1111/j.1753-4887.2001.tb05500.x

17. Martín V, Fabelo N, Santpere G, et al (2010) Lipid alterations in lipid rafts from Alzheimer's disease human brain cortex. Journal of Alzheimer's disease: JAD 19:489-502. https://doi.org/10.3233/JAD2010-1242

18. Wong MW, Braidy N, Poljak A, et al (2017) Dysregulation of lipids in Alzheimer's disease and their role as potential biomarkers. Alzheimer's and Dementia 13:810-827. https://doi.org/10.1016/j.jalz.2017.01.008.

19. Chew H, Solomon VA, Fonteh AN (2020) Involvement of Lipids in Alzheimer's Disease Pathology and Potential Therapies. Frontiers in physiology 11:598. https://doi.org/10.3389/fphys.2020.00598

20. Bazan NG (2005) Lipid signaling in neural plasticity, brain repair, and neuroprotection. Molecular Neurobiology 32:89-103. https://doi.org/10.1385/MN:32:1:089.

21. Adibhatla RM, Hatcher JF (2007) Role of Lipids in Brain Injury and Diseases. Future lipidology 2:403-422. https://doi.org/10.2217/17460875.2.4.403

22. Yamashima T, Ota T, Mizukoshi E, et al (2020) Intake of $\omega-6$ Polyunsaturated Fatty Acid-Rich Vegetable Oils and Risk of Lifestyle Diseases. Advances in Nutrition 11:1489-1509. https://doi.org/10.1093/advances/nmaa072.

23. Isacson O, Brekk OR, Hallett PJ (2019) Novel Results and Concepts Emerging From Lipid Cell Biology Relevant to Degenerative Brain Aging and Disease. Frontiers in neurology 10:1053. https://doi.org/10.3389/fneur.2019.01053

24. Marinissen MJ, Gutkind JS (2001) G-protein-coupled receptors and signaling networks: Emerging paradigms. Trends in Pharmacological Sciences 22:368-376. https://doi.org/10.1016/s01656147(00)01678-3.

25. Zamarbide M, Etayo-Labiano I, Ricobaraza A, et al (2014) GPR40 activation leads to CREB and ERK phosphorylation in primary cultures of neurons from the mouse CNS and in human neuroblastoma cells. Hippocampus 24:733-739. https://doi.org/10.1002/hipo.22263

26. Nakamura MT, Yudell BE, Loor JJ (2014) Regulation of energy metabolism by long-chain fatty acids. Progress in lipid research 53:124-144. https://doi.org/10.1016/j.plipres.2013.12.001

27. Chitre NM, Moniri NH, Murnane KS (2019) Omega-3 Fatty Acids as Druggable Therapeutics for Neurodegenerative Disorders. CNS \& Neurological Disorders - Drug Targets 18:735-749. 
28. Alexander SPH, Christopoulos A, Davenport AP, et al (2019) THE CONCISE GUIDE TO PHARMACOLOGY 2019/20: G protein-coupled receptors. British Journal of Pharmacology 176:S21S141. https://doi.org/10.1111/bph.14748

29. Stoddart LA, Smith NJ, Milligan G (2008) International union of pharmacology. LXXI. Free fatty acid receptors FFA1, -2, and -3: Pharmacology and pathophysiological functions. Pharmacological Reviews 60:405-417. https://doi.org/10.1124/pr.108.00802

30. Tikhonova IG (2017) Application of GPCR structures for modelling of free fatty acid receptors. In: Handbook of Experimental Pharmacology. Springer New York LLC, pp 57-77. https://doi.org/10.1007/164_2016_52.

31. Alexander SPH, Christopoulos A, Davenport AP, et al (2019) THE CONCISE GUIDE TO PHARMACOLOGY 2019/20: G protein-coupled receptors. British Journal of Pharmacology 176:S21S141. https://doi.org/10.1111/bph.14748

32. Le Poul E, Loison C, Struyf S, et al (2003) Functional characterization of human receptors for short chain fatty acids and their role in polymorphonuclear cell activation. Journal of Biological Chemistry 278:25481-25489. https://doi.org/10.1074/jbc.M301403200

33. Alvarez-Curto E, Milligan G (2016) Metabolism meets immunity: The role of free fatty acid receptors in the immune system. Biochemical pharmacology 114:3-13. https://doi.org/10.1016/j.bcp.2016.03.017

34. Feng X-T, Leng J, Xie Z, et al (2012) GPR40: a therapeutic target for mediating insulin secretion (review). International journal of molecular medicine 30:1261-1266. https://doi.org/10.3892/ijmm.2012.1142

35. Hudson BD, Smith NJ, Milligan G (2011) Experimental Challenges to Targeting Poorly Characterized GPCRs. Uncovering the Therapeutic Potential for Free Fatty Acid Receptors. In: Advances in Pharmacology. Academic Press Inc., pp 175-218. https://doi.org/10.1016/B978-0-12-385952-5.00006-3

36. Hara T, Kimura I, Inoue D, et al (2013) Free fatty acid receptors and their role in regulation of energy metabolism. Reviews of Physiology, Biochemistry and Pharmacology 164:77-116. https://doi.org/10.1007/112_2013_13

37. Poitout V (2018) Fatty Acids and Insulin Secretion: From FFAR and Near? Diabetes 67:19321934. https://doi.org/10.2337/dbi18-0027

38. Miletta MC, Petkovic V, Eblé A, et al (2014) Butyrate increases intracellular calcium levels and enhances growth hormone release from rat anterior pituitary cells via the G-protein-coupled receptors GPR41 and 43. PLoS ONE 9:. https://doi.org/10.1371/journal.pone.0107388 
39. Yang Y, Tian X, Xu D, et al (2018) GPR40 modulates epileptic seizure and NMDA receptor function. Science advances 4:eaau2357. https://doi.org/10.1126/sciadv.aau2357

40. Karki P, Kurihara T, Nakamachi T, et al (2015) Attenuation of inflammatory and neuropathic pain behaviors in mice through activation of free fatty acid receptor GPR40. Molecular pain 11:6. https://doi.org/10.1186/s12990-015-0003-8

41. Lonsdale J, Thomas J, Salvatore M, et al (2013) The Genotype-Tissue Expression (GTEx) project. Nature Genetics 45:580-585. https://doi.org/10.1038/ng.2653

42. Nøhr MK, Egerod KL, Christiansen SH, et al (2015) Expression of the short chain fatty acid receptor GPR41/FFAR3 in autonomic and somatic sensory ganglia. Neuroscience 290:126-137. https://doi.org/10.1016/j.neuroscience.2015.01.040

43. Kimura I, Inoue D, Maeda T, et al (2011) Short-chain fatty acids and ketones directly regulate sympathetic nervous system via G protein-coupled receptor 41 (GPR41). Proceedings of the National Academy of Sciences of the United States of America 108:8030-8035.

https://doi.org/10.1073/pnas.1016088108

44. Mayer EA (2011) Gut feelings: the emerging biology of gut-brain communication. Nature reviews Neuroscience 12:453-466. https://doi.org/10.1038/nrn3071

45. Hoyles L, Jiménez-Pranteda ML, Chilloux J, et al (2018) Metabolic retroconversion of trimethylamine $\mathrm{N}$-oxide and the gut microbiota. Microbiome 6:73. https://doi.org/10.1186/s40168-0180461-0

46. van de Wouw M, Boehme M, Lyte JM, et al (2018) Short-chain fatty acids: microbial metabolites that alleviate stress-induced brain-gut axis alterations. Journal of Physiology 596:4923-4944. https://doi.org/10.1113/JP276431

47. Hou Y fang, Shan C, Zhuang S yue, et al (2021) Gut microbiota-derived propionate mediates the neuroprotective effect of osteocalcin in a mouse model of Parkinson's disease. Microbiome 9:. https://doi.org/10.1186/s40168-020-00988-6

48. Hsiao K, Chapman P, Nilsen S, et al (1996) Correlative memory deficits, Abeta elevation, and amyloid plaques in transgenic mice. Science (New York, NY) 274:99-102. https://doi.org/10.1126/science.274.5284.99

49. Samuel BS, Shaito A, Motoike T, et al (2008) Effects of the gut microbiota on host adiposity are modulated by the short-chain fatty-acid binding $G$ protein-coupled receptor, Gpr41. Proceedings of the National Academy of Sciences of the United States of America 105:16767-16772. https://doi.org/10.1073/pnas.0808567105 
50. Zamarbide M, Gil-Bea FJ, Bannenberg P, et al (2018) Maternal imprinting on cognition markers of wild type and transgenic Alzheimer's disease model mice. Scientific reports 8:6434. https://doi.org/10.1038/s41598-018-24710-7

51. Cuadrado-Tejedor M, Hervias I, Ricobaraza A, et al (2011) Sildenafil restores cognitive function without affecting $\beta$-amyloid burden in a mouse model of Alzheimer's disease. British Journal of Pharmacology 164:2029-2041. https://doi.org/10.1111/j.1476-5381.2011.01517.x

52. Dunah AW, Wang Y, Yasuda RP, et al (2000) Alterations in subunit expression, composition, and phosphorylation of striatal N-methyl-D-aspartate glutamate receptors in a rat 6-hydroxydopamine model of Parkinson's disease. Molecular Pharmacology 57:342-352.

53. Laemmli UK (1970) Cleavage of structural proteins during the assembly of the head of bacteriophage T4. Nature 227:680-685. https://doi.org/10.1038/227680a0

54. Chomczynski P, Sacchi N (1987) Single-step method of RNA isolation by acid guanidinium thiocyanate-phenol-chloroform extraction. Analytical Biochemistry 162:156-159. https://doi.org/10.1016/0003-2697(87)90021-2

55. Braak H, Braak E (1991) Neuropathological stageing of Alzheimer-related changes. Acta neuropathologica 82:239-59. https://doi.org/10.1007/BF00308809.

56. Zhang L, Lu W, Chen L, et al (2013) The early changes in behavior and the myelinated fibers of the white matter in the Tg2576 transgenic mouse model of Alzheimer's disease. Neuroscience letters 555:112-117. https://doi.org/10.1016/j.neulet.2013.09.030

57. Avila J, Perry G (2021) A Multilevel View of the Development of Alzheimer's Disease. Neuroscience 457:283-293. https://doi.org/10.1016/j.neuroscience.2020.11.015.

58. Rabbito A, Dulewicz M, Kulczyńska-Przybik A, Mroczko B (2020) Biochemical Markers in Alzheimer's Disease. International journal of molecular sciences 21:. https://doi.org/10.3390/ijms21061989

59. Stoiljkovic M, Horvath TL, Hajós M (2021) Therapy for Alzheimer's disease: Missing targets and functional markers? Ageing Research Reviews 68:101318. https://doi.org/10.1016/j.arr.2021.101318

60. Fonteh AN, Chiang AJ, Arakaki X, et al (2020) Accumulation of Cerebrospinal Fluid Glycerophospholipids and Sphingolipids in Cognitively Healthy Participants With Alzheimer's Biomarkers Precedes Lipolysis in the Dementia Stage. Frontiers in neuroscience 14:611393. https://doi.org/10.3389/fnins.2020.611393

61. Zhang X, Liu W, Zan J, et al (2020) Untargeted lipidomics reveals progression of early Alzheimer's disease in APP/PS1 transgenic mice. Scientific reports 10:14509. https://doi.org/10.1038/s41598-02071510-z 
62. Brown AJ, Goldsworthy SM, Barnes AA, et al (2003) The orphan G protein-coupled receptors GPR41 and GPR43 are activated by propionate and other short chain carboxylic acids. Journal of Biological Chemistry 278:11312-11319. https://doi.org/10.1074/jbc.M211609200

63. Le Poul E, Loison C, Struyf S, et al (2003) Functional characterization of human receptors for short chain fatty acids and their role in polymorphonuclear cell activation. Journal of Biological Chemistry 278:25481-25489. https://doi.org/10.1074/jbc.M301403200

64. Couto MR, Gonçalves P, Magro F, Martel F (2020) Microbiota-derived butyrate regulates intestinal inflammation: Focus on inflammatory bowel disease. Pharmacological Research 159. https://doi.org/10.1016/j.phrs.2020.104947.

65. Kimura I, Ichimura A, Ohue-Kitano R, Igarashi M (2020) Free Fatty Acid Receptors in Health and Disease. Physiological reviews 100:171-210. https://doi.org/10.1152/physrev.00041.2018

66. Wolf A, Bauer B, Abner EL, et al (2016) A Comprehensive Behavioral Test Battery to Assess Learning and Memory in 129S6/Tg2576 Mice. PloS one 11:e0147733.

https://doi.org/10.1371/journal.pone.0147733

67. Kim HJ, Chang K-A, Ha T-Y, et al (2014) S100A9 knockout decreases the memory impairment and neuropathology in crossbreed mice of Tg2576 and S100A9 knockout mice model. PloS one 9:e88924. https://doi.org/10.1371/journal.pone.0088924

68. Lanahan A, Worley P (1998) Immediate-early genes and synaptic function. In: Neurobiology of Learning and Memory. Academic Press Inc., pp 37-43. https://doi.org/10.1006/nlme.1998.3836.

69. Guzowski JF (2002) Insights into immediate-early gene function in hippocampal memory consolidation using antisense oligonucleotide and fluorescent imaging approaches. Hippocampus 12:86-104. https://doi.org/10.1002/hipo.10010

70. Christensen DZ, Thomsen MS, Mikkelsen JD (2013) Reduced basal and novelty-induced levels of activity-regulated cytoskeleton associated protein (Arc) and c-Fos mRNA in the cerebral cortex and hippocampus of APPswe/PS1 $\triangle \mathrm{E} 9$ transgenic mice. Neurochemistry international 63:54-60. https://doi.org/10.1016/j.neuint.2013.04.002

71. Sierksma ASR, Van Den Hove DLA, Pfau F, et al (2014) Improvement of spatial memory function in APPswe/PS1dE9 mice after chronic inhibition of phosphodiesterase type 4D. Neuropharmacology 77:120-130. https://doi.org/10.1016/j.neuropharm.2013.09.015

72. Palop JJ, Chin J, Bien-Ly N, et al (2005) Vulnerability of dentate granule cells to disruption of Arc expression in human amyloid precursor protein transgenic mice. Journal of Neuroscience 25:9686-9693. https://doi.org/10.1523/JNEUROSCI.2829-05.2005 
73. Zamarbide M, Etayo-Labiano I, Ricobaraza A, et al (2014) GPR40 activation leads to CREB and ERK phosphorylation in primary cultures of neurons from the mouse CNS and in human neuroblastoma cells. Hippocampus 24:733-739. https://doi.org/10.1002/hipo.22263

74. Reese LC, Laezza F, Woltjer R, Taglialatela G (2011) Dysregulated phosphorylation of Ca $2+$ /calmodulin-dependent protein kinase II- $a$ in the hippocampus of subjects with mild cognitive impairment and Alzheimer's disease. Journal of Neurochemistry 119:791-804.

https://doi.org/10.1111/j.1471-4159.2011.07447.x

75. Almeida CG, Tampellini D, Takahashi RH, et al (2005) Beta-amyloid accumulation in APP mutant neurons reduces PSD-95 and GluR1 in synapses. Neurobiology of disease 20:187-198. https://doi.org/10.1016/j.nbd.2005.02.008

76. Gylys KH, Fein JA, Yang F, et al (2004) Snaptic changes in alzheimer's disease: Increased amyloid$\beta$ and gliosis in surviving terminals is accompanied by decreased PSD-95 fluorescence. American Journal of Pathology 165:1809-1817. https://doi.org/10.1016/s0002-9440(10)63436-0

77. Tao X, Finkbeiner S, Arnold DB, et al (1998) Ca2+ influx regulates BDNF transcription by a CREB family transcription factor-dependent mechanism. Neuron 20:709-726. https://doi.org/10.1016/s08966273(00)81010-7

78. Seidah NG, Chrétien M (1999) Proprotein and prohormone convertases: a family of subtilases generating diverse bioactive polypeptides. Brain research 848:45-62. https://doi.org/10.1016/s00068993(99)01909-5

79. Bibel M, Barde YA (2000) Neurotrophins: key regulators of cell fate and cell shape in the vertebrate nervous system. Genes \& development 14:2919-2937. https://doi.org/10.1101/gad.841400

80. Schindowski K, Belarbi K, Buée L (2008) Neurotrophic factors in Alzheimer's disease: Role of axonal transport. In: Genes, Brain and Behavior. Blackwell Publishing Ltd, pp 43-56. https://doi.org/10.1111/j.1601-183X.2007.00378.x.

81. O'Bryant SE, Hobson V, Hall JR, et al (2009) Brain-derived neurotrophic factor levels in alzheimer's disease. Journal of Alzheimer's Disease 17:337-341. https://doi.org/10.3233/JAD-2009-1051

82. Holsinger RMD, Schnarr J, Henry P, et al (2000) Quantitation of BDNF mRNA in human parietal cortex by competitive reverse transcription-polymerase chain reaction: Decreased levels in Alzheimer's disease. Molecular Brain Research 76:347-354. https://doi.org/10.1016/S0169-328X(00)00023-1

83. Peng S, Wuu J, Mufson EJ, Fahnestock M (2005) Precursor form of brain-derived neurotrophic factor and mature brain-derived neurotrophic factor are decreased in the pre-clinical stages of Alzheimer's disease. Journal of Neurochemistry 93:1412-1421. https://doi.org/10.1111/j.1471-4159.2005.03135.x 
84. Lue LF, Kuo YM, Roher AE, et al (1999) Soluble amyloid beta peptide concentration as a predictor of synaptic change in Alzheimer's disease. The American journal of pathology 155:853-862. https://doi.org/10.1016/s0002-9440(10)65184-x

85. McLean CA, Cherny RA, Fraser FW, et al (1999) Soluble pool of A $\mathrm{B}$ amyloid as a determinant of severity of neurodegeneration in Alzheimer's disease. Annals of Neurology 46:860-866. https://doi.org/10.1002/1531-8249(199912)46:6<860::AID-ANA8>3.0.CO;2-M

86. Carrasquillo MM, Belbin O, Zou F, et al (2010) Concordant association of insulin degrading enzyme gene (IDE) variants with IDE mRNA, Abeta, and Alzheimer's disease. PloS one 5:e8764. https://doi.org/10.1371/journal.pone.0008764

87. Kilger $\mathrm{E}$, Buehler A, Woelfing $\mathrm{H}$, et al (2011) BRI2 protein regulates $\beta$-amyloid degradation by increasing levels of secreted insulin-degrading enzyme (IDE). Journal of Biological Chemistry 286:37446-37457. https://doi.org/10.1074/jbc.M111.288373

88. Liu XP, Qian X, Xie Y, et al (2014) Betaine suppressed A $\beta$ generation by altering amyloid precursor protein processing. Neurological Sciences 35:1009-1013. https://doi.org/10.1007/s10072-014-1630-y

89. Probst A, Botez G, Tolnay M (1999) [Neuropathological aspects of Alzheimer disease].

Therapeutische Umschau Revue therapeutique 56:88-93. https://doi.org/10.1024/0040-5930.56.2.88

90. Giannakopoulos P, Kövari E, Gold G, et al (2009) Pathological substrates of cognitive decline in alzheimer's disease. Frontiers of Neurology and Neuroscience 24:20-29.

https://doi.org/10.1159/000197881

91. Pooler AM, Noble W, Hanger DP (2014) A role for tau at the synapse in Alzheimer's disease pathogenesis. Neuropharmacology 76:1-8. https://doi.org/10.1016/j.neuropharm.2013.09.018

92. Ferrer I (2004) Stress kinases involved in Tau phosphorylation in Alzheimer's disease, tauopathies and APP transgenic mice. Neurotoxicity Research 6:469-475. https://doi.org/10.1007/BF03033283

93. Chauhan NB, Siegel GJ, Feinstein DL (2005) Propentofylline attenuates tau hyperphosphorylation in Alzheimer's Swedish mutant model Tg2576. Neuropharmacology 48:93-104.

https://doi.org/10.1016/j.neuropharm.2004.09.014

94. Ferrer I, Gomez-Isla T, Puig B, et al (2005) Current advances on different kinases involved in tau phosphorylation, and implications in Alzheimer's disease and tauopathies. Current Alzheimer research 2:3-18. https://doi.org/10.2174/1567205052772713

95. Milligan G, Shimpukade B, Ulven T, Hudson BD (2017) Complex Pharmacology of Free Fatty Acid Receptors. Chemical reviews 117:67-110. https://doi.org/10.1021/acs.chemrev.6b00056 
96. Milligan G, Bolognini D, Sergeev E (2017) Ligands at the Free Fatty Acid Receptors 2/3 (GPR43/GPR41). Handbook of experimental pharmacology 236:17-32.

https://doi.org/10.1007/164_2016_49

97. Hudson BD, Ulven T, Milligan G (2013) The therapeutic potential of allosteric ligands for free fatty acid sensitive GPCRs. Current topics in medicinal chemistry 13:14-25.

https://doi.org/10.2174/1568026611313010004

98. Grundmann M, Bender E, Schamberger J, Eitner F (2021) Pharmacology of free fatty acid receptors and their allosteric modulators. International Journal of Molecular Sciences 22:1-38. https://doi.org/10.3390/ijms22041763.

99. Milligan G, Stoddart LA, Smith NJ (2009) Agonism and allosterism: The pharmacology of the free fatty acid receptors FFA2 and FFA3. British Journal of Pharmacology 158:146-153.

https://doi.org/10.1111/j.1476-5381.2009.00421.x.

100. Watterson KR, Hudson BD, Ulven T, Milligan G (2014) Treatment of type 2 diabetes by free Fatty Acid receptor agonists. Frontiers in endocrinology 5:137. https://doi.org/10.3389/fendo.2014.00137

101. Lonsdale J, Thomas J, Salvatore M, et al (2013) The Genotype-Tissue Expression (GTEx) project. Nature Genetics 45:580-585. https://doi.org/10.1038/ng.2653.

\section{Figures}

a

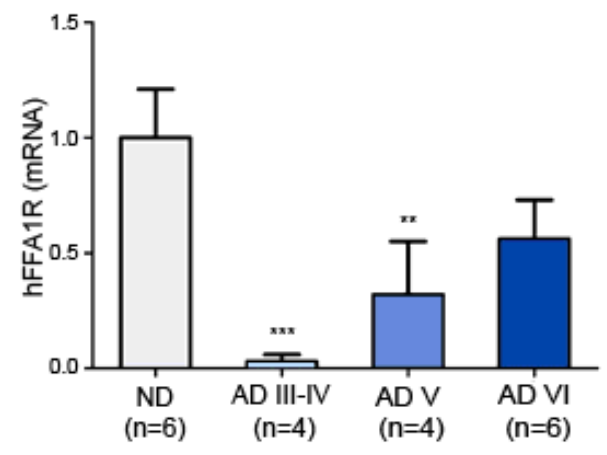

b

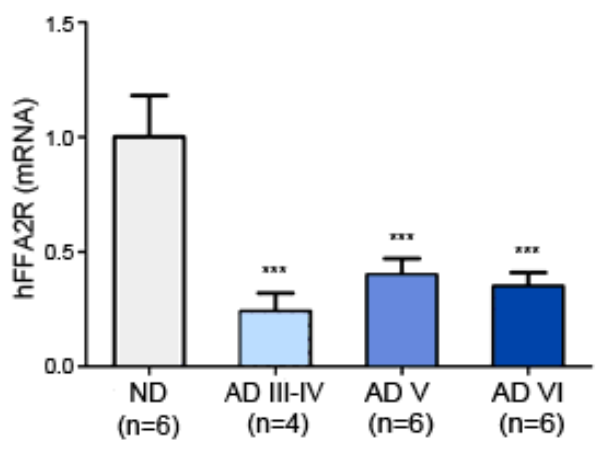

C

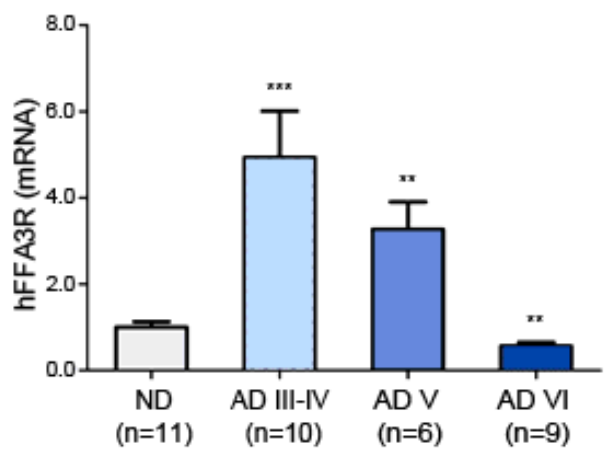

\section{Figure 1}

FFARs in post mortem hippocampus tissue from AD patients. cDNA levels of FFAR in hippocampal sections of AD patients and the corresponding ND controls analyzed by RT-qPCR. Bars represent the receptor expression normalized to that of the corresponding 36B4 internal control. Values are expressed as mean \pm SEM. (A) Expression levels of FFA1R in ND and patients of different stages of AD. (B) Expression levels of FFA2R in ND and patients of different stages of AD. (C) Expression levels of FFA3R in ND and patients of different stages of $A D .{ }^{*} p<0.01,{ }^{\star *} * 0<0.001$ vs ND. 
a

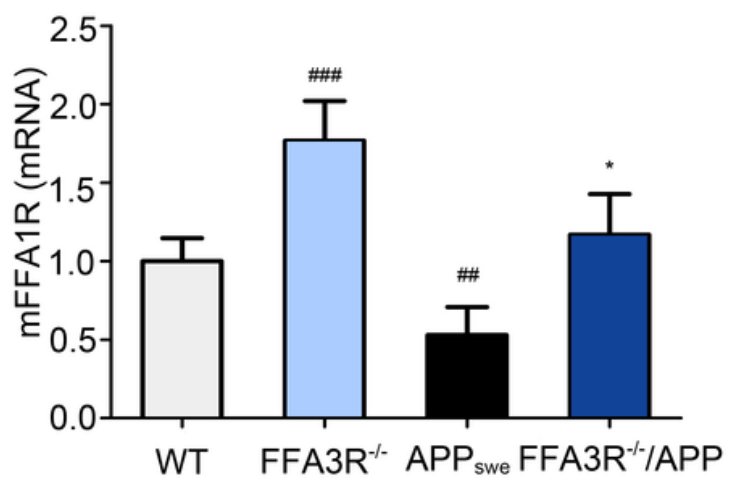

b

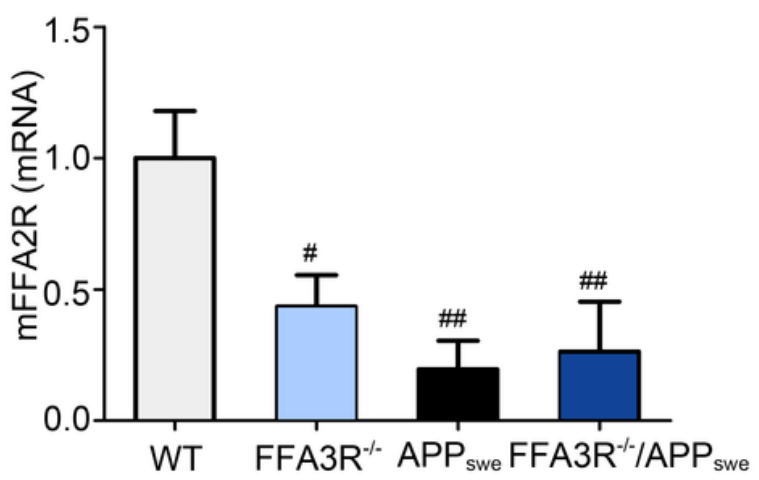

C

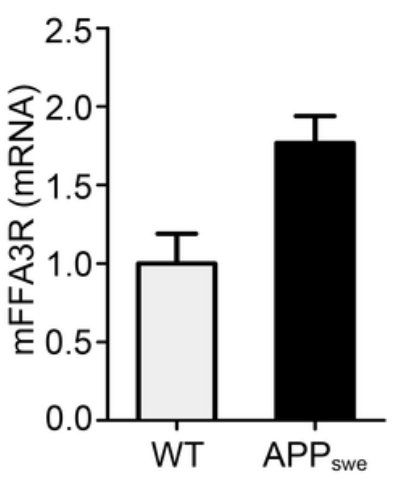

Figure 2

Comparative expression of FFARs in hippocampus of WT and transgenic mice. cDNA levels of FFAR in hippocampus of WT, FFA3R-/-, APPswe and FFA3R-/-/APPswe mice analyzed by RT-qPCR. Bars represent the receptor expression normalized to that of the corresponding 36B4 internal control. Values are expressed as mean \pm SEM $(n=6)$ normalized to the ratio of WT mice. (A) Expression levels of FFA1R. (B)

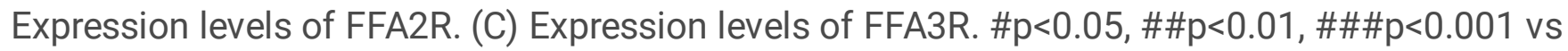
WT.* $p<0.05$ vs APPswe.

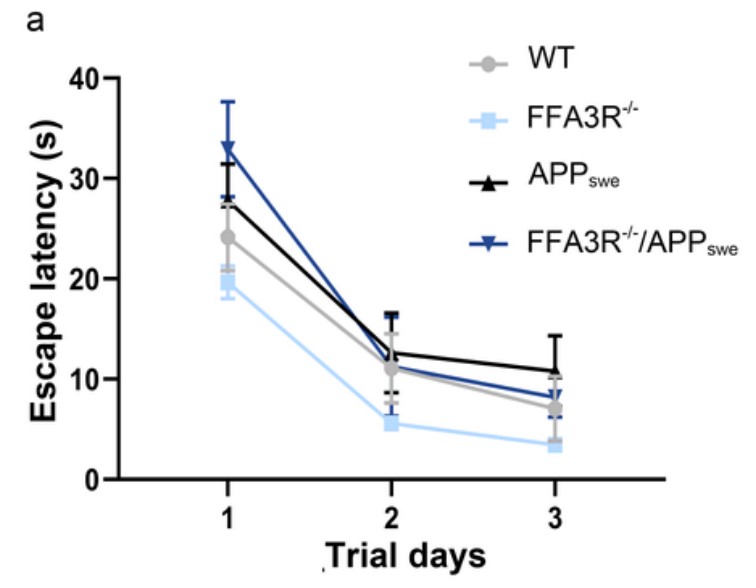

b

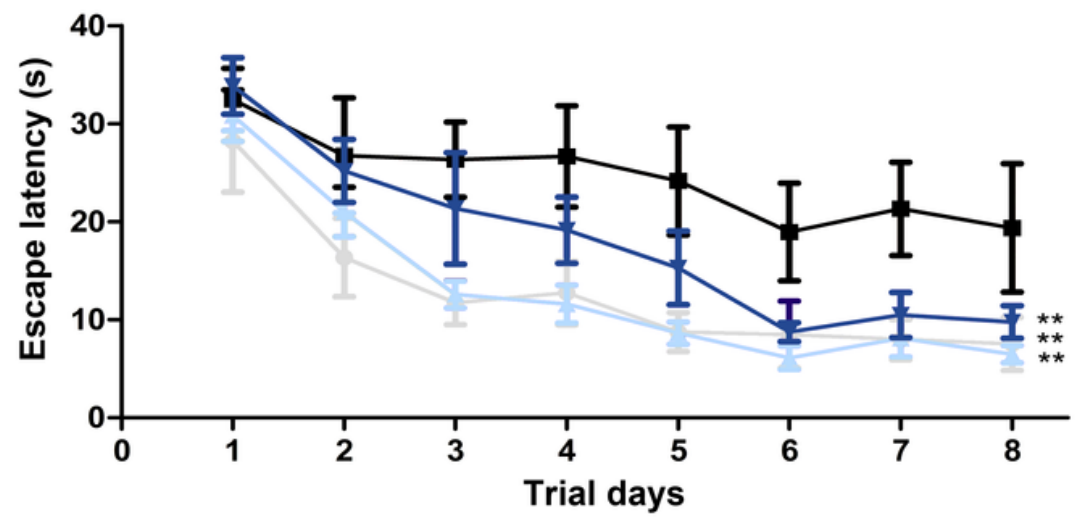

C

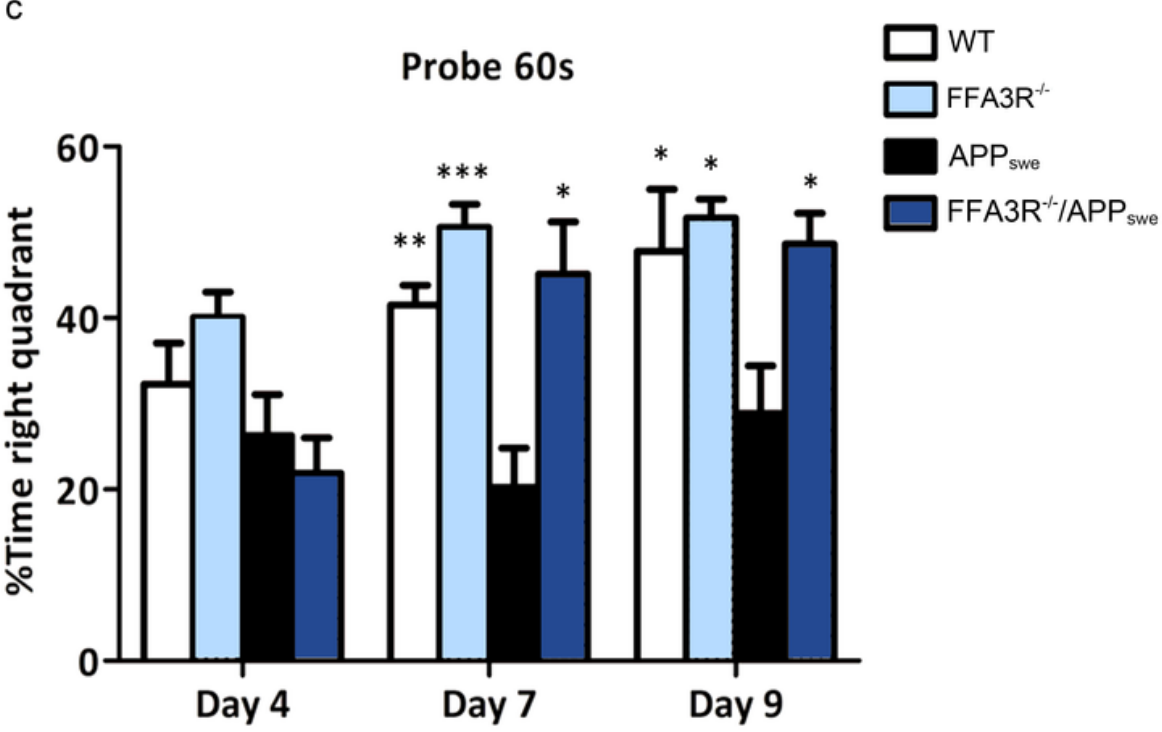




\section{Figure 3}

FFA3R-/-/APPswe mice do not show the cognitive deficit of 12 month old APPswe mice. Escape latency times of the visible- (A) and hidden-platform (B) in the MWM test for the WT, FFA3R-/-, APPswe and FFA3R-/-/APPswe mice in the different trial days. (C) Percentage of time spent searching for the target quadrant of the probe test for the WT, FFA3R-/-, APPswe and FFA3R-/-/APPswe on day 4, 7 and 9. Results are expressed as mean \pm SEM ( $n=10-12$ in each group). ${ }^{*} p<0.05$, ${ }^{\star *} p<0.01,{ }^{\star \star *} p<0.001$ vs APPswe.
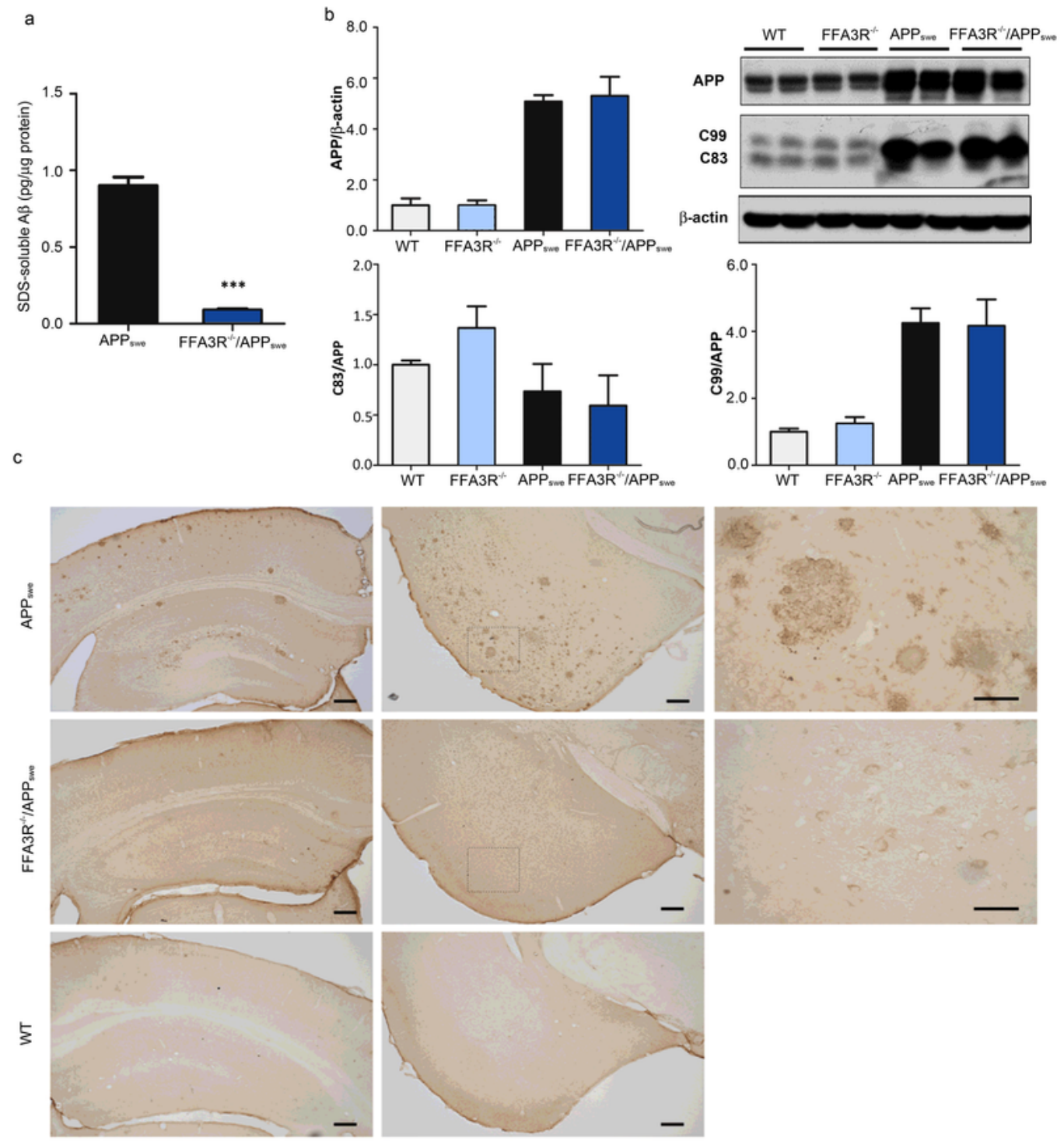

Id

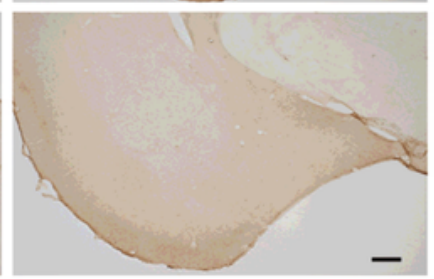

e
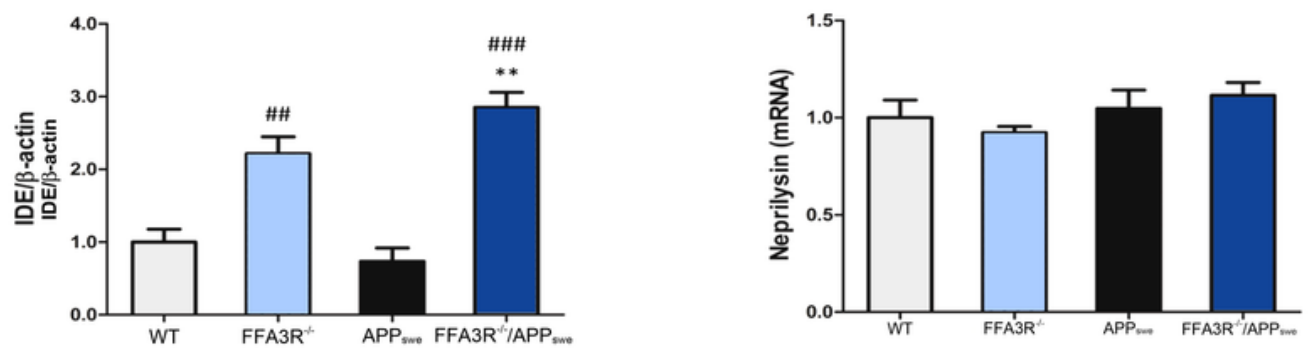

IDE (118 kDa)

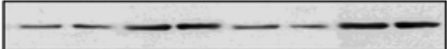

3-actin (42 kDa)

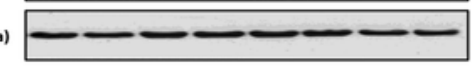




\section{Figure 4}

The FFA3R-/-/APPswe mice show improved $A \beta$ pathology and increased IDE levels. (A) Levels of soluble A 42 in the APPswe and FFA3R-/-/APPswe measured by ELISA. (B) Expression levels of full-length APP and APP carboxy-terminal fragments, $\mathrm{C} 99$ and $\mathrm{C} 83$, quantified by western blot. (C) Immunohistochemistry for 6E10 in hippocampal and entorhinal cortex sections of WT, APPswe and FFA3R-/-/APPswe mice. Positive amyloid plaques are observed only in APPswe mice. Magnification of 5X (Scale bar $=200 \mu \mathrm{m}$ ) in left and middle panels and 40X (Scale bar=50 $\mu \mathrm{m}$ ) in right panels. (D) Levels of IDE analyzed in WT, FFA3R-/-, APPswe and FFA3R-/-/APPswe mice by western blot. We show a representative blot and the quantification of immunoreactive bands. Bars represent the ratio of IDE vs $\beta$ actin. (E) Expression levels of neprilysin analyzed by RT-qPCR. Bars represent the enzyme expression normalized to that of the corresponding 36B4 internal control values. Results are expressed as mean \pm SEM $(n=6)$ normalized to the ratio of WT mice. $\# \# p<0.01$, \#\#\#p<0.001 vs WT. ${ }^{*} p<0.01, * \star \star p<0.001$ vs APPswe.
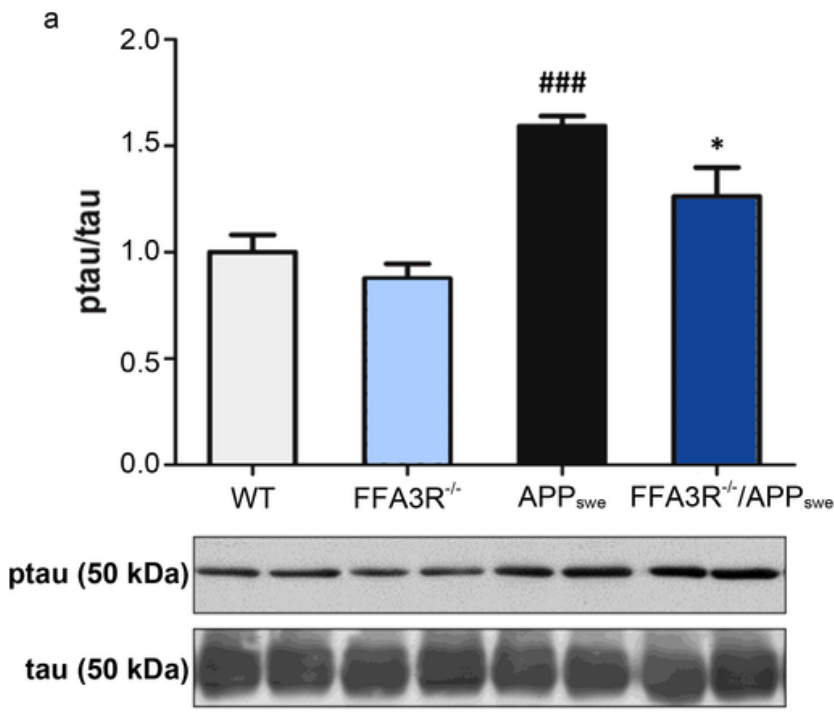

C

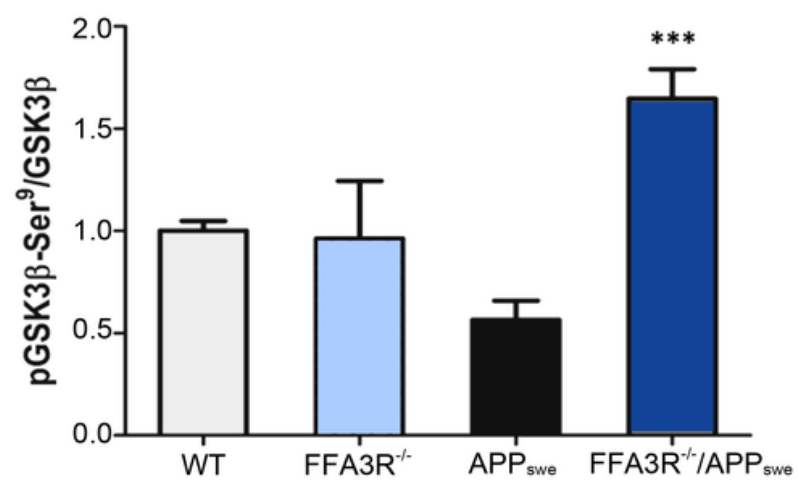

b
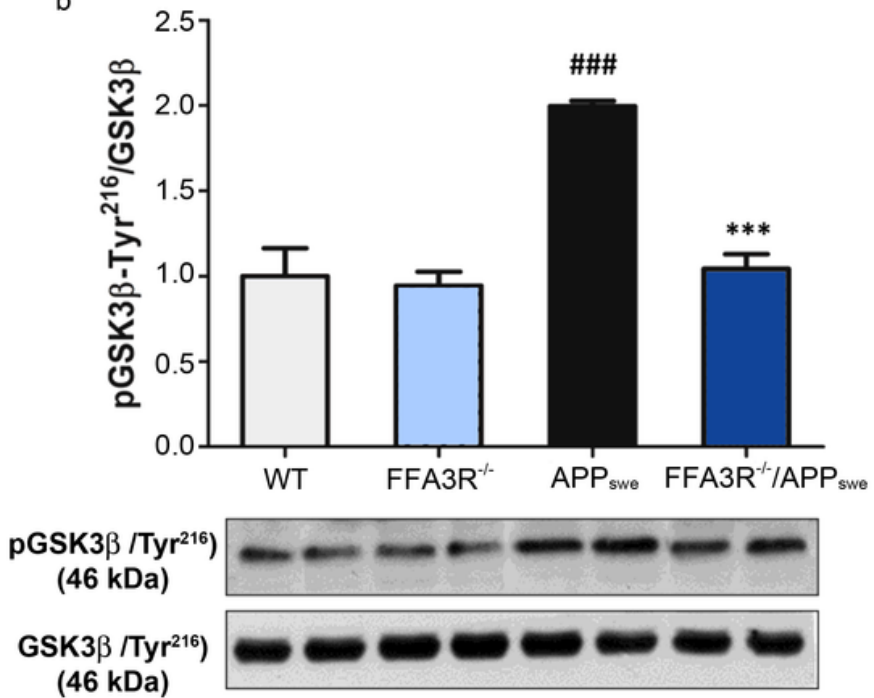

d

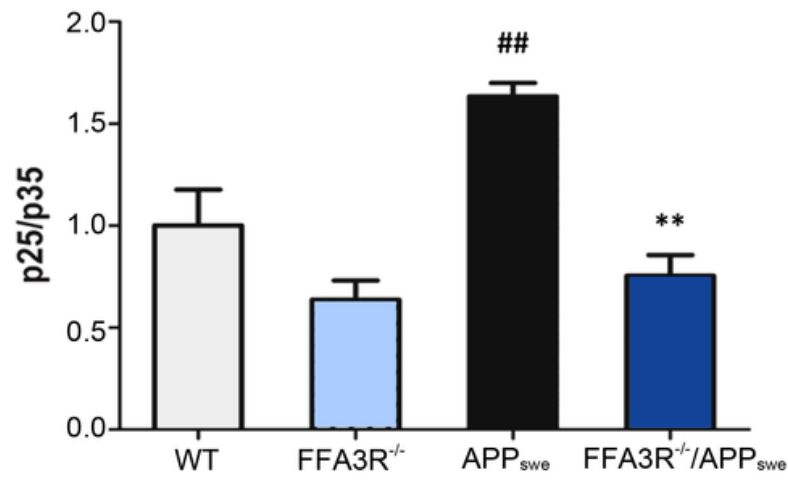

p35 (35 kDa)

p25 (25 kDa) 
Figure 5

The FFA3R-/-/APPswe mice show improved tau pathology. The levels of different proteins involved in tau pathology were analyzed in total hippocampal protein extracts of WT, FFA3R-/-, APPswe and FFA3R-/-/APPswe mice by western blot. We show a representative blot and the quantification of immunoreactive bands for each protein normalized to the ratio of WT mice. The results are expressed as the mean \pm SEM $(n=6)$. Bars represent the ratio of ptau vs tau $(A)$, the ratio of pGSK3 $\beta$ (Tyr216) vs GSK3 $\beta$ (B), the ratio of pGSK3 $\beta$ (Ser9) vs GSK3 3 (C) and the ratio of p25 vs p35 (D). \#\#p<0.01 and \#\#\#p<0,001 vs WT. ${ }^{*} p<0.05,{ }^{*} p<0.01,{ }^{* \star *} p<0.001$ vs APPswe.

a

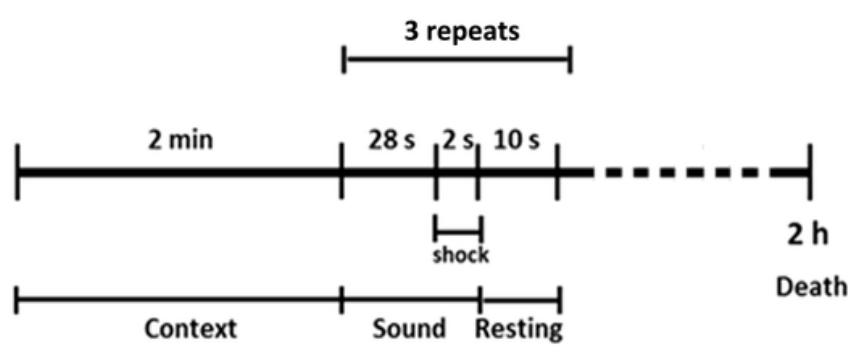

C

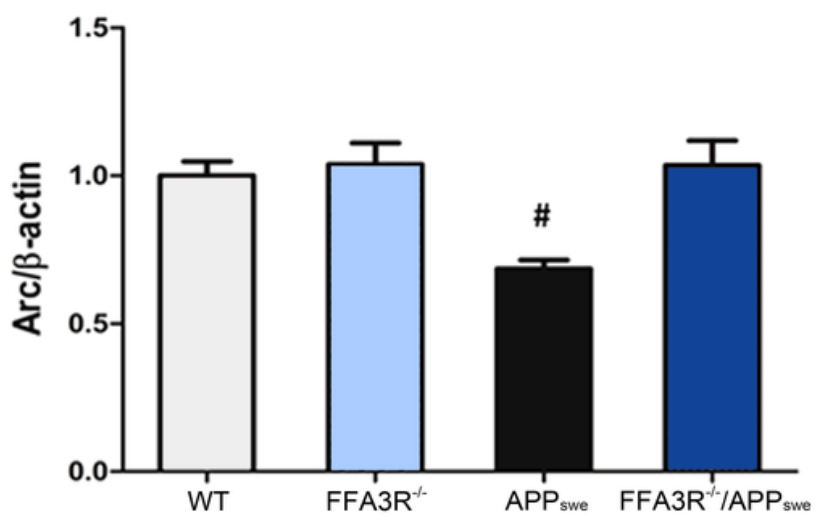

Arc (55 kDa)

$\beta$-actin (42 kDa)

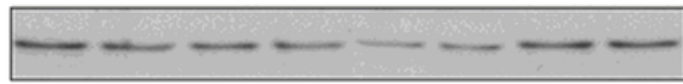

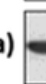

b

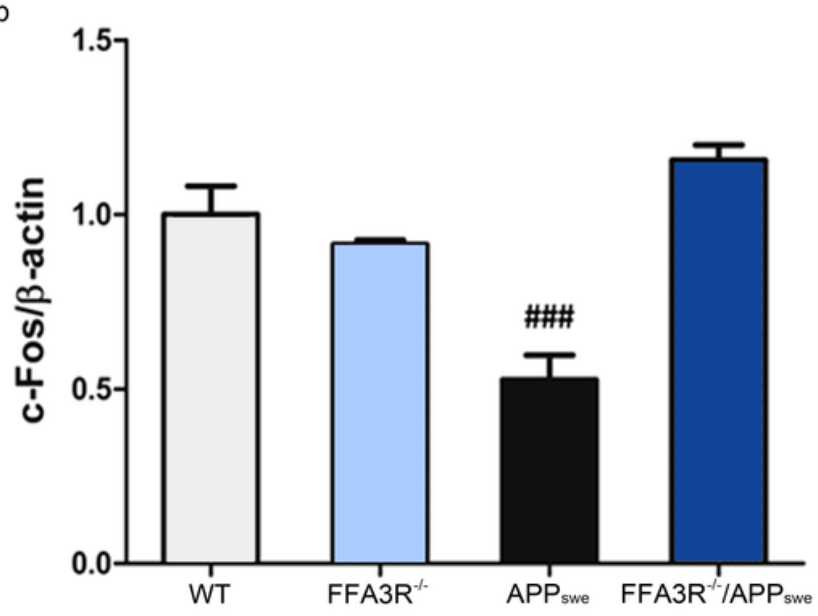

c-Fos (62 kDa)

$\beta$-actin (42 kDa)

d

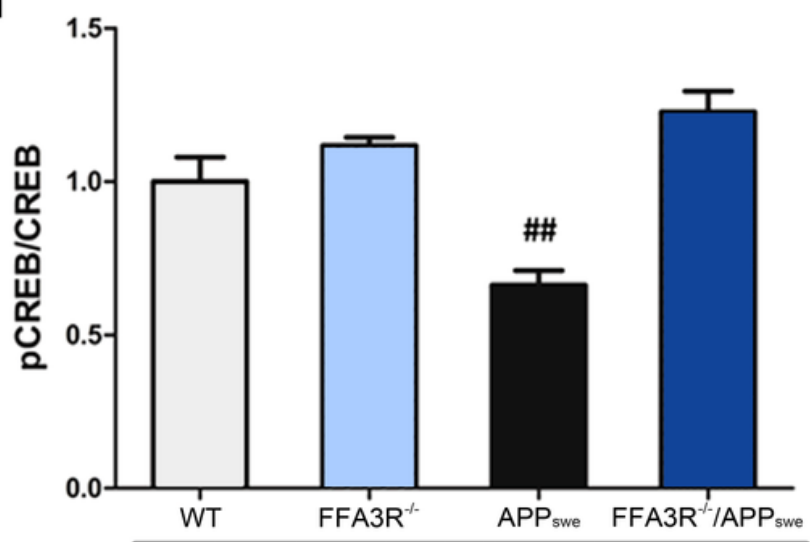

pCREB (43 kDa)

CREB (43 kDa)
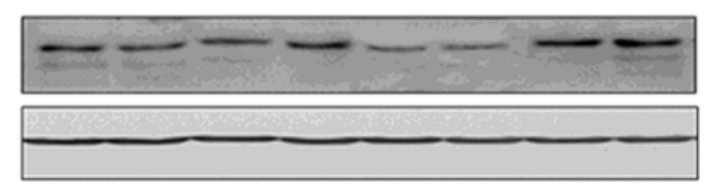

$\mathrm{APP}_{\text {swe }}$

\section{Figure 6}


Induction of memory-associated genes in hippocampal mice samples. (A) Scheme showing the fear conditioning training. (B, C, D) The levels of IEGs were analyzed in WT, FFA3R-/-, APPswe and FFA3R-/-/APPswe mice by western blot. We show a representative blot and the quantification of immunoreactive bands for each protein. The results are expressed as the mean \pm SEM $(n=6)$, and the bars represent the ratio of $c$-Fos vs $\beta$-actin (B), the ratio of Arc vs $\beta$-actin (C), and the ratio of pCREB vs CREB (D) normalized to the ratio of WT mice. $\# p<0.05, \# \# p<0.01$, \#\#\#p<0.001 vs WT.
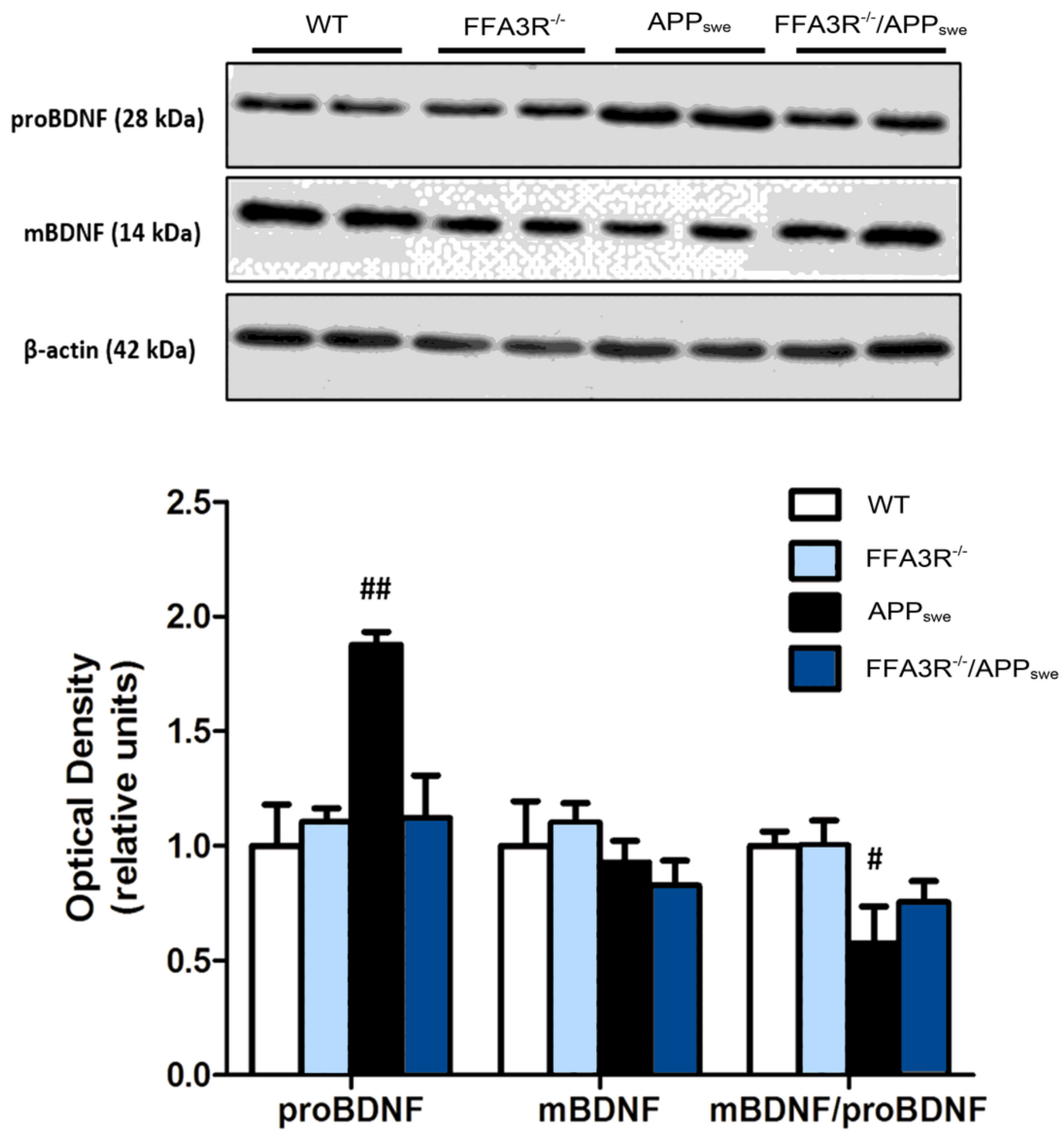

Figure 7 
BDNF maturation is impaired in APPswe mice and restored in FFA3R-/-/APPswe mice. Levels of proBDNF and mBDNF were analyzed in total hippocampal extracts of WT, FFA3R-/-, APPswe and FFA3R-/-/APPswe mice by western blot. We show a representative blot and the quantification of immunoreactive bands for each protein normalized to that of the corresponding $\beta$-actin internal control values. Results are expressed as mean \pm SEM $(n=6)$ normalized to the ratio of WT mice. $\# p<0.05, \# \# p<0.01$ vs WT.
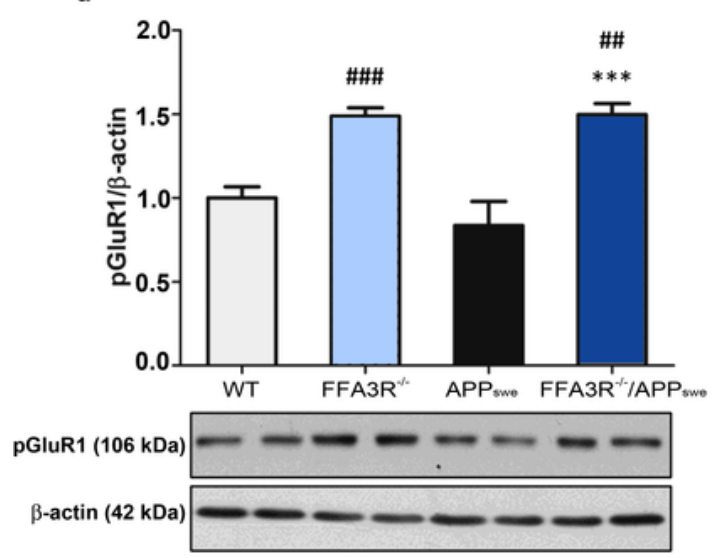

C

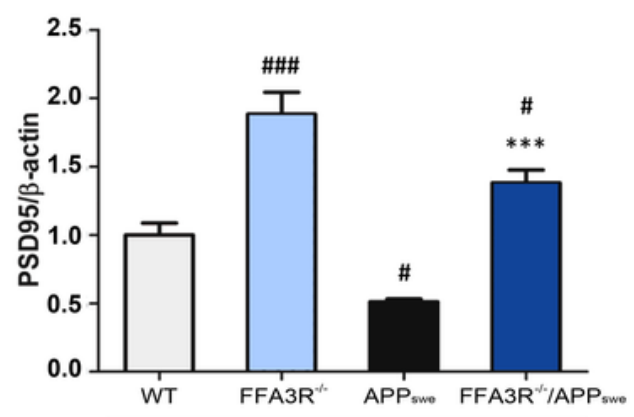

PSD95 (95 kDa)

$\beta$-actin (42 kDa) b
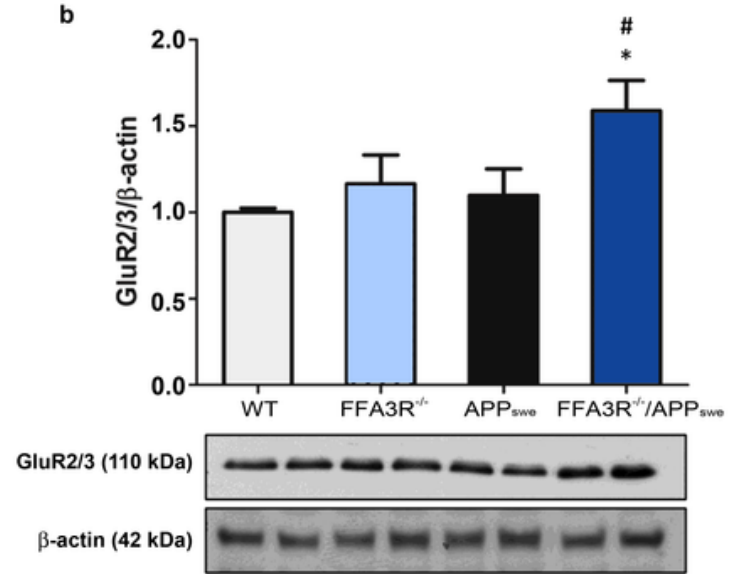

d

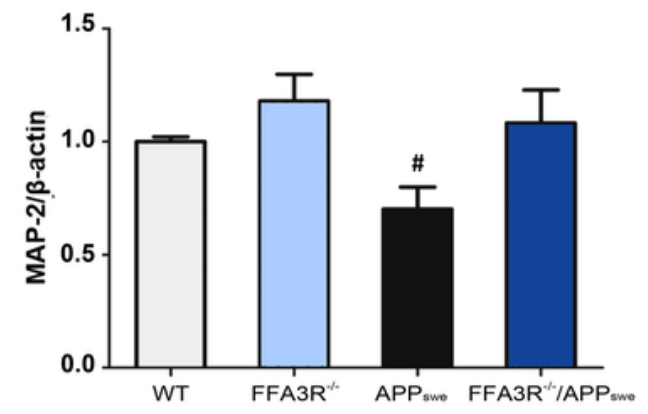

MAP-2 (280 kDa)

$\beta$-actin (42 kDa)

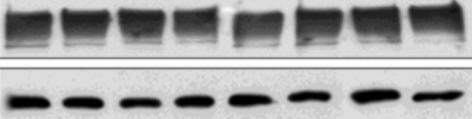

e
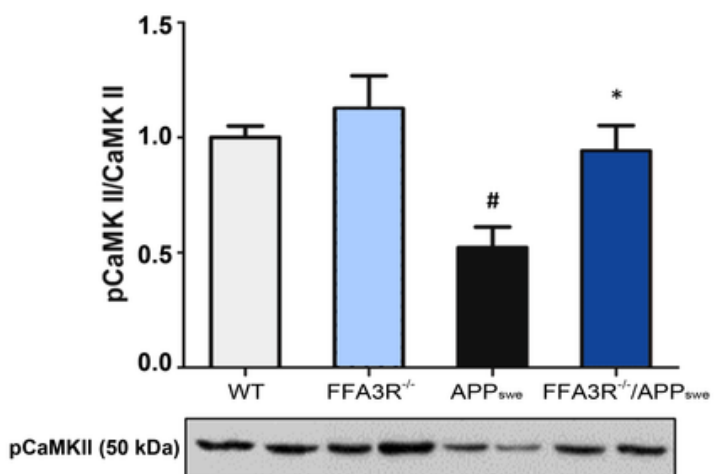

CaMKII (50 kDa)

Figure 8 
Synaptic plasticity markers are restored in the FFA3R-/-/APPswe mice. The levels of synaptic markers in membrane cortex extracts of WT, FFA3R-/-, APPswe and FFA3R-/-/APPswe mice were analyzed by western blot. We show a representative blot and the quantification of immunoreactive bands for each protein. The results are expressed as the mean \pm SEM $(n=6)$ normalized to the ratio of WT mice. (A) AMPA subunit pGLuR1 vs $\beta$-actin. (B) AMPA subunit GluR2/3 vs $\beta$ - actin. (C) Cytoskeletal protein PSD 95 vs $\beta$-actin. (D) Microtubule associated protein MAP-2 vs $\beta$-actin. (E) Phosphorylated LTP mediator CaMK II vs CaMK II. \#p<0.05, \#\#p<0.01, \#\#\#p<0.001 vs WT. * $p<0.05,{ }^{\star \star *} p<0.001$ vs APPswe.

\section{Supplementary Files}

This is a list of supplementary files associated with this preprint. Click to download.

- Supplementary1.docx 